The outcome and impact of the main international commissions on development issues

Working paper No. 30

Frédéric Lapeyre

Policy Integration Department

World Commission on the Social Dimension of Globalization International labour Office

Geneva

May 2004 
Copyright (C) International Labour Organization 2004

Publications of the International Labour Office enjoy copyright under Protocol 2 of the Universal Copyright Convention. Nevertheless, short excerpts from them may be reproduced without authorization, on condition that the source is indicated. For rights of reproduction or translation, application should be made to the Publications Bureau (Rights and Permissions), International Labour Office, CH-1211 Geneva 22, Switzerland. The International Labour Office welcomes such applications.

Libraries, institutions and other users registered in the United Kingdom with the Copyright Licensing Agency, 90 Tottenham Court Road, London W1T 4LP [Fax: (+44) (0)20 7631 5500; email: cla@cla.co.uk], in the United States with the Copyright Clearance Center, 222 Rosewood Drive, Danvers, MA 01923 [Fax: (+1) (978) 750 4470; email: info@copyright.com] or in other countries with associated Reproduction Rights Organizations, may make photocopies in accordance with the licences issued to them for this purpose.

ISBN 92-2-115792-X (printed version)

ISSN 92-2-115793-8 (web version)

First published 2004

The designations employed in ILO publications, which are in conformity with United Nations practice, and the presentation of material therein do not imply the expression of any opinion whatsoever on the part of the International Labour Office concerning the legal status of any country, area or territory or of its authorities, or concerning the delimitation of its frontiers.

The responsibility for opinions expressed in signed articles, studies and other contributions rests solely with their authors, and publication does not constitute an endorsement by the International Labour Office of the opinions expressed in them.

Reference to names of firms and commercial products and processes does not imply their endorsement by the International Labour Office, and any failure to mention a particular firm, commercial product or process is not a sign of disapproval.

ILO publications can be obtained through major booksellers or ILO local offices in many countries, or direct from ILO Publications, International Labour Office, $\mathrm{CH}-1211$ Geneva 22, Switzerland. Catalogues or lists of new publications are available free of charge from the above address, or by email: pubvente@ilo.org

Visit our website: www.ilo.org/publns 


\section{The outcome and impact of the main international commissions on development issues}

\section{Contents}

Foreword

Preface $\mathrm{V}$

Part 1: A Global Assessment of Past Commissions ........................................................................................

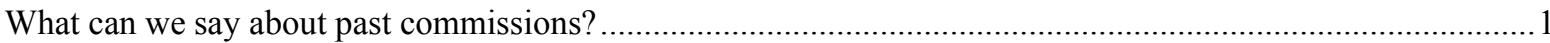

Some challenges for the World Commission on the Social Dimension of Globalization (WCSDG) ................... 4

Part 2 Main International Commissions on Development Issues.................................................................11

2.1 Early days in the United Nations: The Report of a Group of Experts on Measures for the economic development of underdeveloped countries (1951) ....................................................11

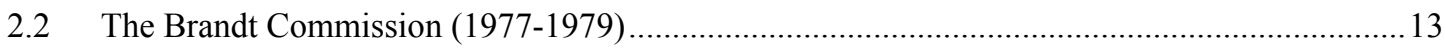

2.3 The Independent Commission on International Humanitarian Issues (1983-1986) ……….......... 19

$2.4 \quad$ The Brundtland Commission (1984-1987) .................................................................................2

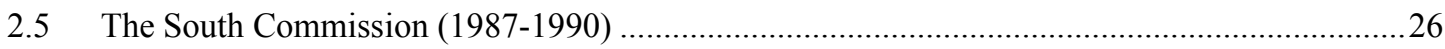

2.6 The Independent Commission on Population and Quality of Life (1991-1996) ........................29

2.7 The Commission on Global Governance (1992-1995) ................................................................33

2.8 The World Commission on Culture and Development (1992-1995) .............................................36

2.9 The World Commission on Dams (May 1998-November 2000) …………..................................40

2.10 International Commission on Intervention and State Sovereignty

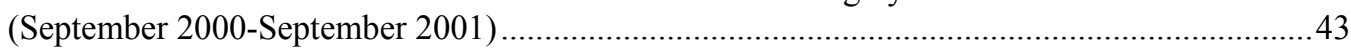

2.11 The Commission on Macroeconomics and Health (2000-2001) …………………………….....47

2.12 The Commission on Human Security (January 2001-December 2002) .......................................51

Part 3: Description of International Commissions' Work Process and Funding..........................................57

3.1 Independent Commission on International Development Issues..................................................57

3.2 Independent Commission on International Humanitarian Issues .................................................58

3.3 World Commission on Environment and Development............................................................5

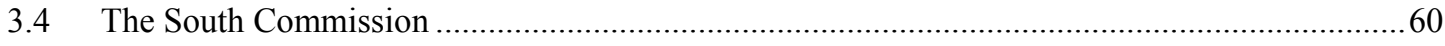

3.5 Independent Commission on Population and Quality of Life .....................................................61

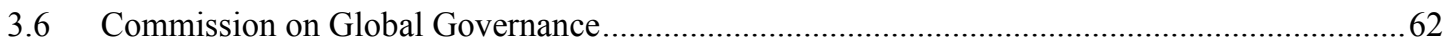

3.7 World Commission on Culture and Development....................................................................64

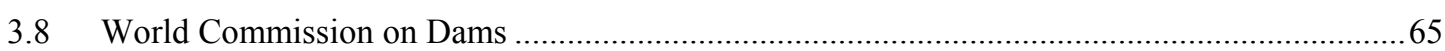

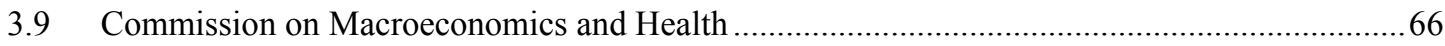

3.10 International Commission on Intervention and State Sovereignty ……………….....................66

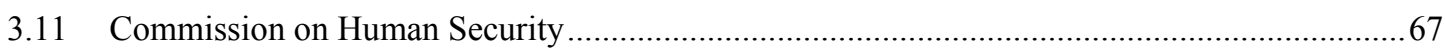





\title{
Foreword
}

In February 2002, the ILO established an independent World Commission on the Social Dimension of Globalization, co-chaired by President Tarja Halonen of Finland and President Benjamin Mkapa of Tanzania and comprising 26 eminent commissioners from a wide range of walks of life and different parts of the world, each serving in their individual capacity. Its broad goals were: to identify policies for globalization that reduce poverty, foster growth and development in open economies, and widen opportunities for decent work; to explore ways to make globalization inclusive, so that the process can be seen to be fair for all, both between and within countries; to promote a more focused international dialogue on the social dimension of globalization; to build consensus among key actors and stakeholders on appropriate policy responses; and to assist the international community forge greater policy coherence in order to advance both economic and social goals in the global economy.

The report of the World Commission, A fair globalization: Creating opportunities for all, was released on 24 February 2004. It is available on the Commission's website www.ilo.org/public/english/wcsdg/index.htm.

A secretariat was established by the ILO to support the Commission. Among other tasks, it compiled information and commissioned papers on different aspects of the social dimension of globalization. The aim was to provide the Commission with documentation and data on a wide range of options and opinions concerning subjects within its mandate, without committing the Commission or individual Commissioners to any particular position on the issues or policies concerned.

Material from this background work is being made available as working papers, as national and regional reports on meetings and dialogues, and in other forms. Responsibility for the content of these papers and publications rests fully with their authors and their publication does not constitute an endorsement by the World Commission or the ILO of the opinions expressed in them.

\author{
Gerry Rodgers \\ Director \\ Policy Integration Department
}





\title{
Preface
}

The Technical Secretariat to support the World Commission on the Social Dimension of Globalization first prepared a synthesis of ILO activities on the Social Dimension of Globalization (published as Working Paper No. 1 in this series). Documentation on the work and outcomes of other major commissions, an ideas bank, a database and knowledge networks of experts and social actors were subsequently developed. These networks have dealt with several topics, including: inclusion at the national level for the benefits of globalization to reach more people; local markets and policies; cross-border networks of production to promote decent work, growth and development; international migration as part of the Global Policy Agenda; international governance (including trade and finance); the relationship between culture and globalization; and values and goals in globalization. Gender and employment aspects were addressed throughout this work. The Reports on the Secretariat's Knowledge Network Meetings are available on the Commission's web site or in a special publication from the ILO (ISBN 92-2-115711-1).

During the course of these activities, a number of substantive background papers were prepared, which are now made available for wider circulation in the Policy Integration Department's Working Paper series (Nos. 16 to 38), as well as on the Commission's website.

The present paper was prepared by Professor Frédéric Lapeyre of the Institut d'études du développement, Université catholique de Louvain, and analyses the context, mandate, work process and outcomes and impact of the major international independent commissions on development issues and draws the major lessons learned of such commissions for the World Commission on the Social Dimension of Globalization.

\author{
Rolph van der Hoeven \\ Manager, Technical Secretariat \\ World Commission on the Social Dimension of Globalization
}

May 2004 



\section{Part 1: A Global Assessment of Past Commissions}

Very little has been written on the contribution of the work of international independent commissions to the world of ideas on development issues and their policy implications. This background paper aims at filling that lacuna. It should complement the work done within the United Nations Intellectual History Project which is analysing the evolution of key ideas and concepts of international economic and social development born or nurtured under UN auspices and their impact on wider thinking and international action. ${ }^{1}$ This paper analyses from a comparative perspective the context, mandate, work process, outcomes and impact of a series of independent commissions on development issues and draws the main lessons learnt from the commissions' work over the past 50 years. Table 1.1 outlines the main international commissions on development issues.

\section{What can we say about past commissions?}

In the 1980s and 1990s, the world community has made increasing use of independent commissions to address new global challenges. If we look at the various mandates, we must acknowledge the extent to which the work and objectives were very often ahead of their time in promoting and nurturing innovative ideas and visions that challenged conventional wisdom. The independent commissions, together - and in a complementary way - with the UN world conference system, worked as a transmission belt for ideas to respond to common global concerns. The continuum of these commissions' reports and world conferences maintained the momentum towards the mobilization of the community of states and public opinion to address global challenges. That process increasingly involved members of civil society. In most cases, the commissions have been part of the process of enrichment of the concept of development by adding new dimensions to it such as the social, the cultural, the human rights, the ethical dimension or the environmental one.

First it is important to note that the commissions' work never started from scratch but was based on the general academic and political debates related to the specific mandates. However, commissions' reports did an effective job of conceptualizing new ideas and defining them in a very effective - and also more consensual way — in order to maximize their impact on public opinion, political leaders and academics. For example, several reports have contributed to the evolution of some key concepts such as the concepts of sustainability in the Brundtland report or the concept of state sovereignty in both the Commission on Global Governance and the Commission on Intervention and State Sovereignty. The idea of a responsibility to protect promoted by the latter commission led to that of military intervention for human protection purposes, an exceptional and extraordinary measure that implies an evaluation of the issues from the point of view of those seeking or needing support, rather than those who may be considering intervention.

\footnotetext{
${ }^{1}$ See the first volume of the UN Intellectual History Project Series: Louis Emmerij, Richard Jolly, and Thomas G. Weiss, Ahead of the Curve? UN Ideas and Global Challenges (Indiana University Press: 2001).
} 
The Brundtland Commission succeeded, for example, in popularizing the term "sustainable development" and raising popular awareness of issues at the environment and development interface. It has contributed to the emergence of a new comprehensive development framework leading to the development of an integrated policy approach, which includes economic, social and environmental dimensions. Nevertheless, the sustained impact of the Brundtland report is linked to the fact that it took place as part of a vast process of increasing global awareness about environmental and developmental issues. Therefore, the concept of sustainable development received further impetus and became the focus of world attention with the adoption of agenda 21, the Rio Declaration, the Earth Summit and the Johannesburg conference. The Bundling report was an important step in this process.

The commissions developed and popularized some key notions such as sustainable development, global governance or mutual interest, stimulated reaction and contributed to some degree of acceptance for new concepts and measures. Their principal challenge is to mobilize political will for multilateral action. It is the commissions' task to articulate a vision of global cooperation that may inspire a nation's leaders and people to intensify their collective endeavours.

Although their impact has been very uneven as we will see in Part 2, the commissions have been effective vehicles for the circulation of new ideas and for fruitful North-South debates. Many have successfully introduced new common concerns and new approaches to global challenges and some of them - too few some would say - have generated new international and national policies. They have more or less successfully influenced the international agenda and their cumulative impacts are in some cases substantial. The Brundtland Commission and the Commission on Global Governance have contributed, for example, to the emergence of a new development paradigm in the post-Washington Consensus era by emphasizing the need to reform the global institutional architecture, to question the growth objective as an end in itself, or to give a growing voice to civil society.

By creating global awareness and highlighting some complex links between crucial issues such as environment and development, human security and humanitarian intervention, or culture and development, the commissions have contributed to changing the way political leaders perceived global problems. They have played an important role in changing the lenses through which policy- and decision-makers view many dimensions of economic and social development. The commissions' work has also generated a wealth of data and analysis on a vast number of human rights, environment and development issues. The reports and all the background papers associated with them have stimulated research and mobilized the academic community on some key issues. Moreover, the work process of the commissions has facilitated the exchange of information and encouraged a process of action-oriented reflection and research that has fed and sustained international discussion in both academic, policy-making and public opinion circles.

If the major goal of the commissions is to raise awareness on common problems, to promote some changes in conventional wisdom and to confront global challenges, one can say that many of them have been very effective, and clearly had some success in this respect. From this perspective, attention should not focus too narrowly on immediate responses by governments to commissions' recommendations. The true significance of the commissions' reports must be measured less by the way in which their recommendations have been translated into immediate action at both national and international levels than by their effectiveness in creating global awareness on crucial issues and contributing to the evolution of development thinking and practices in the medium and long-term. 
The outcome and impact of a commission must be considered from a dynamic perspective and be assessed within a long-term perspective on paradigm changes, political forces mobilized, governments' commitments, the involvement of civil society and the evolution of the concept of development toward a more comprehensive approach. In the first phase (raising consciousness) many of the reports considered here have been very effective. But it is also right to say that too often reports' recommendations progress no further and sit on a shelf without reaching the second vital phase, that of implementation.

As a result of past implementation failure of the Brandt Commission's recommendations, for example, and of several other commissions' recommendations for a better world, independent commissions are considered by many cynics as expensive and futile exercises to force-feed international cooperation to members of the international community who have very different interests, priorities and objectives. They argue that recommendations of such commissions have rarely found their way into the body politic and that their impact has often been slight in terms of direct policy implementation of commissions' recommendations. In evaluating the extent to which recommendations have changed into concrete policies and behaviours, it is disappointing to see the poor results of many of them. But successes and failures depend upon political will or lack thereof. From the futuristic proposals of the Brandt report about taxing the use of global commons, to the reform of the Bretton Woods institutions and the now traditional 0.7 per cent target for Official Development Assistance which has been recalled by several commissions or the establishment of an economic security council proposed by the Commission on Global Governance, the history of independent international commissions is full of neverimplemented proposals that have contributed to a general feeling of the ineffectiveness of Commission work. The lack of implementation structures is very damaging to the real impact of a report.

An important point too often forgotten in the work of the commissions is that world politics matter. Most of the reports are weak in seeing how it is possible to move to the stage of concrete measures and implementation of what has been recommended. What is missing in the last part of many reports, in order to complement their agendas for action, is a cautious analysis of the political economy of reforms, to identify the actors who can support such recommendations and their feasibility as regards global politics. The main weakness of the independent commissions is linked to the fact that their work does not take place in a political vacuum and they were inadequate in the implementation phase and its political implications, notably in the track record of their predecessors.

Commissions' reports are based on an assumption of global concern and mutual interest and have not done enough to deal with underlying conflicts. Most of the recommendations affect power bases and the problem is that power cannot be redistributed without weakening one side relative to the other. The politics of national interests are still the basic organizing principle of the international community. The commissions' reports are not taking into account the political economy of the reforms they call for at the national or international level. Dudley Seers made the point about the Brandt Commission that some of its members had endorsed proposals that "they had turned down as government officials of their respective countries". He wondered what the self-same Commissioners would do "if they were suddenly recalled to Government service". ${ }^{2}$ The Commission on Intervention and State Sovereignty was, for example, very cautious in the wording of the report. It avoided the use of the notions of right to intervene or human intervention to forestall sterile conflicts among members and the rejection of its recommendations by a

\footnotetext{
${ }^{2}$ Dudley Seers, 1980, « North-South: Muddling morality and mutuality », Third World Quarterly,
} vol.II, no.4. 
large number of governments. A consensus was built on the notion of responsibility to protect which was less confrontational with the principles of sovereignty which is one of the overarching tenets of the United Nations.

Gro Harlem Brundtland underlined the lesson to be learnt from the past two decades of development policy: "It is not ideas that are lacking in development cooperation, but political will". ${ }^{3}$ The members of independent commissions are aware of the limits to both their analysis and the effectiveness of their recommendations, as the Brandt Commission stressed in the introduction of its report: "The extent to which the international system will be made more equitable is essentially a matter of political decision." The Brandt and South Commission, for example, came out with some concrete recommendations that were not implemented because most Western governments remained indifferent. Too often, the arguments in reports are based on the premise of North-South and East-West mutual interests, but the grounds are weak and remained unsubstantiated.

The reality is that commissions have no coercive powers to implement their recommendations. Thus, it is easier to obtain political will to accept a report which is lowkey and does not differ too much from conventional wisdom. The risk here is to try to be too consensual and to incorporate that constraint in the nature and content of the report, which then becomes very weak in innovative and path-breaking proposals. Willy Brandt recalled that "the remarkable thing was that after long and sometimes tiring discussions ... we were able to present a report which was accepted by everyone who had participated in our work and, of course, that then includes elements of compromise. That is the reality of the world." ${ }^{4}$

However, as Commissions are independent they do not have to take into consideration (as opposed to the UN World Conference) bargaining issues among states as well as among different interests or groups. This is their strength. It is much easier to reach an agreement - about the precise implications of ideas and some basic recommendations to address global challenges - between independent members than between governments with different priorities. But most members of independent commission who serve in their personal capacity have a background dominated by government service (very often former prime ministers, ministers or political leaders); until now very few of them were representatives of the emerging global civil society despite its increasing role in the international agenda setting process.

\section{Some challenges for the World Commission on the Social Dimension of Globalization (WCSDG)}

Building on the work done by previous Independent commissions, the UN World Conferences, and the Millennium Conference Agenda, the World Commission on the Social Dimension of Globalization will especially face the following challenges:

\footnotetext{
${ }^{3}$ Gro Harlem Brundtland, 2000, Speech for the Conference organised in February 2000 by the Development and Peace Foundation on « 20 years after the Brandt Report », quoted in Development Cooperation News from the Deutsche Stiftung für internationales Entwicklung (DES), No.3, MayJune 2000, p.30-31.

${ }^{4}$ Willy Brandt, 1982, "North-South dialogue”, Studia Diplomatica, vol.xxxv, no.3, p.194.
} 
- Listening and responding to world voice: Timing is very important in the success of any commission. From that perspective, the potential impact of the WCSDG's work is considerable as it takes place at the heart of today's core theoretical and policy debates and controversies. It is a great opportunity but it is also a great responsibility. Expectations are high and scepticism about the ability of the UN System to promote globalization with a human face is mounting because of the poor results of the Copenhagen Plus Five Conference in Geneva in 2000. Some growing groups of the population, in fear of the rising tide of new poverty, exclusion, unemployment, job insecurity, the phenomenon of the working poor, inequalities or even public sector and social welfare reforms, react in an increasingly sceptical manner to the prevailing rhetoric about the beneficial effects of globalization. The 1990s were characterized by growing public awareness of the threats posed by the rise in economic and social insecurity in the new global world. ${ }^{5}$ The recent demonstrations in Seattle and Genoa during the G8 Summits or the Porto Alegre Social Forum have shown that it is necessary to strengthen dialogue between citizens, international organizations and governments. They reflect the emergence of a vast social movement in favour of the more democratic governance of globalization and greater consideration for the human dimension in the setting of global objectives. The preservation or strengthening of social cohesion is essential for world stability and prosperity. That is why the protests of an ever-growing number of citizens through associations and NGOs must not go unheeded. The success of the new development agenda will depend on its capacity to live up to citizens' expectations and provide political solutions to their concerns. Such is the challenge facing the WCSDG. In the face of active or passive protests related to the social impact of globalization some changes are beginning to emerge or are the subject of intensive debate. The opening of the dialogue and of consensusbuilding mechanisms at the local, national and international level to NGOs and civil society movements is a good example of this trend. A further example of the response to new social demands is the promotion of the concept of corporate social responsibility and the launching of the global compact.

- Stimulating ownership: Global and national reforms are not a harmonious and gradual process. They are disruptive and uncertain processes that challenge the established hierarchy and framework of regulation. To be successful, it is crucial to overcome the hostility or indifference of the various actors involved. Participatory processes in democratic regimes ensure that the concerns regarding the risks of change are not only heard but also addressed. As a result, these processes dissipate much of the resistance to change. ${ }^{6}$ Participation is thus essential to make systemic change more acceptable. When individuals have a voice in shaping changes and activating recuperation mechanisms, they are more likely to accept or even embrace them. Problem number one of the $21^{\text {st }}$ century is that of social ties because competitiveness, transition and development always imply the mobilization of some forms of social creativity that can not be stimulated in a context of social fragmentation. This can take place only if there is a real process of ownership and the various social actors decide to cooperate, because mobilization is an ex ante process which occurs well before the goal - sustainable development - has been achieved. The participants thus take a bet on the future and choose to cooperate despite their diverging and sometimes conflicting objectives, that is to say, they place their trust in

\footnotetext{
${ }^{5}$ Bhalla, A. and F. Lapeyre, 1999, Poverty and Exclusion in a Global World, (London: Macmillan).

${ }^{6}$ Stiglitz, J., 1998, "Towards a New Paradigm for Development: Strategies, Policies, and Processes," 1998 Prebisch Lecture (Geneva: UNCTAD)
} 
a project which they consider to be fair and whose success is in their mutual interest. ${ }^{7}$ Here is the main challenge of the WCDG and one of the key lessons from previous commissions. Its work and recommendations must launch a multi-actor and multilevel process of ownership. Too often, good reports from independent commissions do not achieve the success they deserve because of lack of ownership: the processes of the reforms they supported were dead before they began. From this perspective the WCSDG has a great advantage - the legitimacy and credibility of its initiating body, the ILO. Since its creation, the ILO has been promoting a greater coherence between economic and social policies. Sustainable development in a global world can be achieved only if it is based on social justice, a core objective of the ILO since the Philadelphia Declaration in 1944.

- Getting visibility: The impact of the work of an independent commission benefits highly from an open, visible and participatory process based on a good communication strategy and the organization of public hearings, seminars and other events during and after its work. These initiatives contribute to the spread of ideas and recommendations and increase the influence of the report. Thus, the success of the WCSDG's work will depend especially on: how the report is presented (it must not be intended as a technical document; the commitment of its members to promoting a large public debate; the authority and personality of individual members; the links built with the academic world, with business, with civil society organizations and, ultimately with senior staff members from the WCSDG's Secretariat, the advisory panels of experts and other experts preparing background papers, who provided an invaluable resource base for the WCSDG's work and the drafting of its final report.

- Reforming global architecture and strengthening UN values: From the beginning, the UN has been centrally concerned with global governance - what we might call an 'enabling framework' on the global scale. As we will see in Part 2, the debate on reforming the Bretton Woods institutions is not new. In the 1951 report, T. W. Schultze and Arthur Lewis were already calling for reforming those institutions to meet the challenge of financing the economic development of underdeveloped countries. In a new global era marked by strong interdependencies, roles and responsibilities must be redesigned for better governance. A greater participation of civil society in decision-making processes is required. The UN system must also return to the front stage after a long period dominated by the voice of Bretton Woods' institutions and the WTO. Indeed, human development involves concern for international action to ensure the overall framework that allows individuals to exercise their human capabilities. From that perspective, the UN Charter is a strong political document. Contrary to hearsay, the document is infused with human values and human concerns from its opening words:

"We the peoples of the United Nations determined

- $\quad$ to save succeeding generations from the scourge of war, which twice in our lifetime has brought untold sorrow to mankind and

- $\quad$ to reaffirm faith in fundamental human rights, in the dignity and worth of the human person, in the equal rights of men and women and of nations large and small, and

\footnotetext{
${ }^{7}$ Reynaud, J-D, 1997, Les règles du jeu, (Paris: Armand Colin), p. 141
} 
- to establish conditions under which justice and respect for the obligations arising from treaties and other sources of international law can be maintained, and

- $\quad$ to promote social progress and better standards of life in larger freedom.”

In Chapter IX, article 55, the UN roles and obligations with respect to international economic and social cooperation are spelt out more fully.

"With a view to the creation of conditions of stability and well being which are necessary for peaceful and friendly relations among nations based on respect for the principle of equal rights and self-determination of peoples, the United Nations shall promote:

- higher standards of living, full employment, and conditions of economic and social progress and development;

- solutions of international economic, social, health and related problems; and international cultural and educational cooperation; and

- universal respect for, and observance of, human rights and fundamental freedoms for all without distinction as to race, sex, language, or religion."

In the mid-1940s, these words were extraordinary and unprecedented. ${ }^{9}$ The Charter recognized the need for development action on a global scale - to improve the standards of living of people universally and to promote full employment and conditions of economic and social progress in all parts of the world. The economic and social advances were also to be pursued with full respect for human rights and fundamental freedoms. As we said in Ahead of the Curve, Volume 1 of the UNIHP series, these visionary goals and objectives were far ahead of their time. The world of 1945 was still a world in which half the global population lived under colonial rule and much of the rest in conditions of dictatorship. Yet the words were drafted and accepted by governments of the very countries in charge of these situations. In a period when the UN system is under attack, it is worthwhile to iterate the revolutionary values and criteria of the Charter and the Declaration. Human development over the past decade has elaborated the concepts, analytical frameworks and policy agenda needed to link the legal world of rights and principles with the dynamic world of economic and social development. Building on the innovative ideas of Mahbub ul Haq and Amartya Sen, human development has developed a people-centred view of the goals and processes of development, with concepts and tools linked systematically to the policies and actions needed to implement a pattern of development which over time leads to the fulfilment of rights. Used in this way, human development can help to define the values and criteria needed for a style of development consistent with the Charter and the Universal Declaration.

- Developing a concrete policy agenda for action at national and global level: One of the main criticisms of previous commissions' work was the lack of such a concrete agenda for action. The WCSDG will gain legitimacy and credibility in launching a "bank" of innovative policies which are contributing - or can contribute - to making globalization work for all. Indeed, economic globalization without governance is a dual process of integration and exclusion which is creating winners and losers all around the world. A growing part of the world population which is suffering from socio-economic precariousness and exclusion are increasingly sceptical about the opportunities created by globalization and are attracted by

${ }^{8}$ The Charter (1997), article 55, p. 37.

9 Jolly, R., L. Emmerij, D. Ghai, and F. Lapeyre, The contributions of the United Nations to Development Theory and Practices, UNIHP Series (Indiana University Press: Forthcoming 2003). 
nationalist or fundamentalist alternative projects. Therefore, it is crucial to show that the benefits from globalization can be distributed more equally and contributed to poverty alleviation. From this perspective, employment must be at the heart of the new integrated development strategy and the ILO Decent Work agenda can provide a central core of recommendations in that domain. The ILO country studies launched within the ILO World Employment Programme (WEP), in the early 1970s are a good example of what could be an appropriate analytical and operational framework to promote policies considering integration into the global economy not as an end in itself but as a mean for human development. ${ }^{10}$ The WEP became an impressive showcase of a UN system-wide effort to try to shift the development focus back to people and to respond to a widely felt problem. The ILO's work in the 1970s enriched and elaborated the earlier concept of employment and strategies to deal with it by relating both directly to the situations and needs of developing countries. In brief, the ILO-WEP brought employment — and people and human needs — back to the centre of development strategy. Another good experience was the preparatory work for the UN Conference Habitat II in 1996. The UN launched the "Best Practices Initiative" to assist national committees to prepare their own national action plans before Istanbul. This initiative helped identify where concrete improvements have been made in human settlements around the world. Hundreds of communities and cities were thus able to learn and exchange problem-solving experiences. Over 100 national committees contributed more than 700 examples of "best practices."

${ }^{10}$ ILO, Towards Full Employment: A Programme for Columbia (Geneva: ILO, 1970); ILO, Matching Employment Opportunities and Expectations: A Programme of Action for Ceylon (Geneva: ILO, 1971). ILO, Employment, Incomes and Equality: A Strategy for Increasing Productive Employment in Kenya (Geneva: ILO, 1972). 
Table 1: Main International Commissions on Development Issues

\begin{tabular}{|c|c|c|c|c|c|}
\hline $\begin{array}{c}\text { Name of } \\
\text { commission }\end{array}$ & Duration & Origin of the initiative & Chair ed by & $\begin{array}{l}\text { Number of } \\
\text { members }\end{array}$ & Report \\
\hline $\begin{array}{c}\text { Independent } \\
\text { Commission on } \\
\text { International } \\
\text { Development Issues }\end{array}$ & 1977- 979 & $\begin{array}{l}\text { Idea originated from } \\
\text { Robert McNamara, } \\
\text { President, World Bank. }\end{array}$ & Willy Brandt & 20 & $\begin{array}{l}\text { 1980, North-South : A } \\
\text { Programme for Survival; } \\
\text { 1983, Common Crisis, } \\
\text { North-South : Cooperation } \\
\text { for World Recovery }\end{array}$ \\
\hline $\begin{array}{c}\text { Independent } \\
\text { Commission on } \\
\text { International } \\
\text { Humanitarian Issues }\end{array}$ & $1983-1988$ & $\begin{array}{l}\text { Initiative taken by group } \\
\text { of eminent persons in } \\
\text { response to GA } \\
\text { resolution, adopted in } \\
1981 \text {, for a new } \\
\text { international } \\
\text { humanitarian order. }\end{array}$ & $\begin{array}{c}\text { Sadruddin } \\
\text { Aga Khan and } \\
\text { Hassan } \\
\text { bin Talal }\end{array}$ & & $\begin{array}{l}\text { 1988, Winning the Human } \\
\text { Race }\end{array}$ \\
\hline $\begin{array}{c}\text { World Commission } \\
\text { on Environment and } \\
\text { Development }\end{array}$ & 1984-1987 & $\begin{array}{l}\text { Commission established } \\
\text { by GA resolution } \\
\text { adopted in } 1983\end{array}$ & $\begin{array}{l}\text { Gro Harlem } \\
\text { Brundtland }\end{array}$ & 23 & 1987, Our Common Future \\
\hline South Commission & $1987-1990$ & $\begin{array}{l}\text { Initiative of the prime } \\
\text { Minister of Malaysia } \\
\text { Dr. Mahathir Mohamad } \\
\text { at the non-aligned } \\
\text { Summit Meeting in } \\
\text { Harare in September } \\
1986\end{array}$ & $\begin{array}{l}\text { Julius K. } \\
\text { Nyerere }\end{array}$ & 28 & 1990, Challenge to the South \\
\hline $\begin{array}{l}\text { Commission on } \\
\text { Population and } \\
\text { Quality of Life }\end{array}$ & 1991-1996 & $\begin{array}{l}\text { Launched at the } \\
\text { common initiative of } \\
\text { several international } \\
\text { organizations working } \\
\text { in the population field }\end{array}$ & $\begin{array}{l}\text { Maria de } \\
\text { Lourdes } \\
\text { Pintasilgo }\end{array}$ & 20 & $\begin{array}{l}\text { 1996, Caring for the Future: } \\
\text { Making the Next Decades } \\
\text { Provide a Life Worth Living }\end{array}$ \\
\hline $\begin{array}{l}\text { Commission on } \\
\text { Global Governance }\end{array}$ & $1992-1995$ & $\begin{array}{l}\text { Idea initiated by Willy } \\
\text { Brandt in 1990, who } \\
\text { brought together the } \\
\text { members of the Brandt, } \\
\text { Brundtland, South and } \\
\text { Palme commissions to a } \\
\text { meeting in Stockholm. }\end{array}$ & $\begin{array}{l}\text { Ingvar } \\
\text { Carlsson } \\
\text { and } \\
\text { Shridath } \\
\text { Ramphal }\end{array}$ & 26 & $\begin{array}{l}\text { 1995, Our Global } \\
\text { Neighbourhood }\end{array}$ \\
\hline $\begin{array}{l}\text { World Commission } \\
\text { on Culture and } \\
\text { Development }\end{array}$ & 1992-1995 & $\begin{array}{l}\text { Initiative from the } 26^{\text {th }} \\
\text { Session of the General } \\
\text { Conference of } \\
\text { UNESCO in } 1991 \text {, } \\
\text { followed by a resolution } \\
\text { of the UN General } \\
\text { Assembly }\end{array}$ & $\begin{array}{l}\text { Javier Pérez } \\
\text { de Cuéllar }\end{array}$ & 19 & 1995, Our Creative Diversity \\
\hline $\begin{array}{l}\text { World Commission } \\
\text { on Dams }\end{array}$ & $1998-2000$ & $\begin{array}{l}\text { The World Bank and the } \\
\text { World Conservation } \\
\text { Union }\end{array}$ & Kader Asmal & 12 & $\begin{array}{l}\text { 2000, Dams and } \\
\text { Development: A New } \\
\text { Framework for Decision } \\
\text { Making }\end{array}$ \\
\hline $\begin{array}{c}\text { International } \\
\text { Commission on } \\
\text { Intervention and } \\
\text { State Sovereignty }\end{array}$ & $2000-2001$ & $\begin{array}{l}\text { UN Secretary General } \\
\text { Millennium Report and } \\
\text { the Canadian } \\
\text { Government }\end{array}$ & $\begin{array}{l}\text { Gareth Evans } \\
\text { and } \\
\text { Mohammed } \\
\text { Sahnoun } \\
\end{array}$ & 12 & $\begin{array}{l}\text { 2001, The Responsibility to } \\
\text { Protect }\end{array}$ \\
\hline $\begin{array}{l}\text { The Commission on } \\
\text { Macroeconomics and } \\
\text { Health }\end{array}$ & $2000-2001$ & $\begin{array}{l}\text { UN Secretary General } \\
\text { Millennium Report and } \\
\text { the WHO }\end{array}$ & Jeffrey Sachs & 19 & $\begin{array}{l}\text { 2001, Macroeconomics and } \\
\text { Health: Investing in Health } \\
\text { for Economic Development }\end{array}$ \\
\hline $\begin{array}{l}\text { Commission on } \\
\text { Human Security }\end{array}$ & 2001-2002 & $\begin{array}{l}\text { UN Secretary General } \\
\text { Millennium Report and } \\
\text { the Japanese } \\
\text { Government }\end{array}$ & $\begin{array}{l}\text { Sadako Ogato } \\
\text { and } \\
\text { Amartya Sen }\end{array}$ & 12 & 2003, Human Security Now \\
\hline
\end{tabular}




\title{
Part 2 Main International Commissions on Development Issues
}

\author{
2.1 Early days in the United Nations: The Report of a \\ Group of Experts on Measures for the economic \\ development of underdeveloped countries (1951)
}

\section{Context}

In the late 1940s, when the United Nations became involved in the debate on economic and social development in underdeveloped countries, very few contemporary books dealing were with these issues except for the work of Eugene Stanley and Kurt Mandelbaum. ${ }^{11}$ The pioneers of development such as Lewis, Myrdal, Nurkse, Hirschman, or Rostow would publish their classics later in the mid-1950s. Nevertheless, towards the end of the 1940s and in the early 1950s one outstanding report from an independent group of experts was published by the UN, with far-reaching repercussions on development thinking and practices during the decade and even after.

On 15 August 1950, the ECOSOC had passed a resolution on full employment requesting the Secretary-General of the United Nations "to appoint a small group of experts to prepare, in the light of the current world situation and of the requirements of economic development, a report on employment and underemployment in underdeveloped countries". ${ }^{12}$ Its group of experts was composed of Theodore W. Schultz (United States), Arthur W. Lewis (United Kingdom), Alberto Baltra Cortez (Chile), D. R. Gadgil (India) and George Hakim (Lebanon). At the request of the group, G. Hakim served as Chair. It is worthwhile to mention that this group included two subsequent Nobel Prize winners: Arthur Lewis and Theodore Schultz.

During the preparation of the report the experts were informed of work already done or currently being undertaken on problems in this field by the Secretariats of the United Nations and of the specialized agencies. They submitted their report in April 1951. ${ }^{13}$ This report and its recommendations led to in-depth discussion in the ECOSOC during its Thirteenth Session (August 1951), and had a major impact on development thinking at that time.

\section{Mandate}

The experts had been asked to study the problem of unemployment and underemployment, and they proposed to classify unemployment in underdeveloped countries - defined as countries where per capita real income was low as compared to industrialised countries into four categories: cyclical, seasonal, technological and disguised unemployment. They

\footnotetext{
${ }^{11}$ Eugène Stanley, 1944, World Economic Development (Montreal: ILO); Kurt Mandelbaum, 1945, The Industrialisation of Backward Areas, (Oxford : Basil Blackwell).

${ }^{12}$ No. 29 (XI)

13 United Nations, Measures for the Economic Development of Underdeveloped Countries, document E/1986, (New York : United Nations : 1951).
} 
left out of their terms of reference the problem of cyclical unemployment, which was the result of cyclical business fluctuations that are usually generated in the industrially advanced countries, because this subject had been investigated by a previous group of experts. ${ }^{14}$

According to Schultz and his team, the main remedy for technological unemployment and for underemployment was to create new employment opportunities rapidly, both in agriculture and in new industries. This was the task of economic development, and it is for this reason that the experts concentrated on measures for economic development rather than on measures to reduce unemployment. Thus the scope of the report was much broader than indicated in the ECOSOC resolution and integrated analysis and recommendations of measures required for the economic development of the countries concerned.

\section{Outcome and impact}

The experts' recommendations on action to be taken to promote economic development were classified in two groups. First, the domestic actions to be implemented by the governments of underdeveloped countries, which were related to preconditions of economic development, technology, population growth, the principles of development planning, and domestic capital formation. Secondly, the international actions to implemented by the United Nations and other international agencies to overcome the obstacles to economic development of underdeveloped countries.

The expert group took strong positions for major social changes towards social justice as a precondition of economic development. Far from many drab international reports to come, "Measures for Economic Development" included a strong critique about the domestic obstacles to economic development. In particular, in its section on land tenure, the report stated: "In many underdeveloped countries, the cultivators of the soil are exploited mercilessly by a landlord class, which perform no useful social function. This class contrives to secure itself the major part of any increase in agriculture yields, and is thus a millstone around the necks of the tenants, discouraging them from making improvements in agriculture and, in any case, leaving them too little income from which they might save to invest in the land. In such countries, land reform abolishing this landlord class is an urgent prerequisite of agriculture progress."

The analysis of the preconditions of economic development by the expert team and their recommendations were probably the most radical parts of the report. Indeed, the experts recommended that the governments of underdeveloped countries make clear to their people their willingness "to take vigorous action to remove the obstacles to free and equal opportunity which blunt the incentives and discourage the effort of their people. Under this head, we include land reform, abolition of privileges based on race, colour, caste or creed, the establishment of taxation upon a progressive basis, and a programme of mass education."

\footnotetext{
${ }^{14}$ United Nations, National and International Measures for Full Employment, op. cit. See also the discussion of that report in L. Emmerij, R. Jolly and T. Weiss, (2001) Ahead of the Curve (New York: Indiana Press) in Chapter 1.
} 
However, at that time, these radical recommendations led to some strong objections from members of the Council. For example, the French representative in ECOSOC, ${ }^{15}$ stressed that underdeveloped countries had never before been incited by UN recommendations to burst "the bonds of castes, creed and race" or to revolt against the inertia of the ruling class "whose main interest is the preservation of its own wealth and privileges". ${ }^{16}$ From an outside academic perspective, Peter Bauer criticized the strong focus of the report on the preconditions of economic development, which were defined by the experts as psychological, social, legal and administrative. He rejected the analysis of the expert group on the way "inequality and privilege act as a major obstacle to development", arguing that "at an early stage of economic development preoccupations with egalitarian ideas may serve to retard the growth of real income, including the real income of the poorer classes". ${ }^{17}$

In many ways, this report set the basis for the following decades' debates on development issues by pointing out as early as 1951 the need to increase development assistance, to reform the Bretton Woods institutions to meet the challenge of financing economic development of underdeveloped countries, to promote development planning or to act against the instability of the price of primary goods and the deterioration of the terms of exchange of those goods.

Finally, the group of experts took up in more detail the idea of a United Nations fund for economic development, which had been initially proposed in 1948 and frequently debated since then within the UN system. They recommended formally that the UN should establish an International Development Authority "to assist the underdeveloped countries in preparing, coordinating and implementing their programmes of economic development; to distribute to underdeveloped countries grants-in-aid for specific purposes, to verify the proper utilization of such grants, and to study and report on the progress of development programmes". ${ }^{18}$

\section{$2.2 \quad$ The Brandt Commission (1977-1979)}

\section{Context}

In 1977, Robert McNamara, President of the World Bank, called upon Willy Brandt to assume the chair of the "independent commission for international development issues" more well known as "The North-South Commission". But it is interesting to note that the World Bank is conspicuously not among the long list of institutions which provided money or hospitality. Moreover, the Brandt Commission had nobody to report to.

\footnotetext{
${ }^{15}$ United Nations Economic and Social Council, Document E/CN.1/SR 108-32 (summary record of the relevant meetings of the Commission (New York: United Nations : 1951).

${ }^{16}$ United Nations, Measures for the Economic Development of Underdeveloped Countries, op. cit., paragraphs 36 and 37.

${ }^{17}$ Peter Bauer, "The United Nations Report on the Economic Development of Under-Developed countries “, Economic Journal 63 (March 1953), p.213.

${ }^{18}$ United Nations, Measures for the Economic Development of Underdeveloped Countries, op. cit., recommendation 14 , p. 95.
} 
Willy Brandt played a key role in convincing well-known statesmen and experts from various developing and developed countries to join the North-South Commission and to invest their time and energy in being part of it. The Commission was not so much composed of experts as of highly experienced politicians. Among the 21 members of the Commission, there were one former President, three former Prime Ministers and several other ambassadors and senior members of national and international governmental bodies. Willy Brandt chaired the Commission.

One of the characteristics of the Brandt Commission was the balanced composition of the members between developed and developing countries. When Willy Brandt composed the Commission he was concerned about the need to avoid members from the South being in a minority that would have reduced the impact and credibility of the recommendations. However, the report suffered from the composition of the Commission. Four of the five northern politicians members of the Commission were socialist - Willy Brandt, Olaf Palme, Edgar Pisani and Jan Pronk. It led to a pronounced pro-southern Report which failed to take into account the North's interests and the limits of the mutual interest thesis. This anti-North bias has considerably limited the report's chance of success in terms of implementation.

The importance of the political and historical context. The problem of the Brandt Report was the unpropitious timing of its publication in 1980. It was proposing a global Keynesian social pact based on an increasing development assistance from the developed countries when the neoliberal counter-revolution was gaining ground in both politics and academia. It also coincided with the election of Margaret Thatcher in the United Kingdom and later Ronald Reagan in the United States which marked a general shift away from the Keynesian paradigm among the developed countries' governments.

\section{New International Economic Order}

Moreover, the Brandt report was deeply rooted in the Group of 77's demands for a new international economic order initiated in 1974 at the Sixth Special Session of the General Assembly. The G-77 had pushed throughout the 1970s for an effective North-South dialogue on the (NIEO) which most developed countries resisted. With the world economic recession and the debt crisis in the early 1980s, the balance of power changed between North and South. The G-77 proposals for radical changes became a dead letter and so too did the idea to continue the North-South dialogue.

The North-South Summit in 1981 in Cancun which followed a proposal of the Brandt Commission led to a general disappointment about the whole process initiated by the Brandt Commission. The failure of that attempt at dialogue between 24 heads of government signalled the definitive rejection by the major developed countries of the NIEO agenda and the weakening of the G-77 on the international scene. Because the developed countries were not enthusiastic to continue the dialogue on a broader participation of developing countries in the management of the global economy it remained an isolated episode.

The Brandt Commission's recommendation regarding a global stimulus through a 20-year Marshall Plan for developing countries was not taken seriously either. Instead, the debt crisis and the multiplication of structural adjustment programmes in developing countries obliged most to carry the full burden of adjustment themselves, with far too little international support. The developing countries were obliged to set aside their demands for 
a NIEO and give priority to implementing structural adjustment programmes in order to have access to the IMF facilities. The burden of adjustment was borne by debtor countries, in contrast to the approach proposed by Keynes 40 years earlier. As a consequence of the bottomless pit of debt servicing, the early 1980s was characterized by a massive transfer of resources out from Latin America and Africa.

The Commission was probably too optimistic about the opportunity of raising development assistance and transcending North-South ideological conflicts through an effective NorthSouth dialogue. The report contained a set of well-intentioned formulas but it failed to acknowledge the imbalance in the distribution of power in the North-South dialogue and the obstacles to the reform of the world economic system. Most developed countries in the early 1980s were not willing to commit themselves to such recommendations.

Finally, the analytical framework of the Brandt Commission was based on a North-South vision of global challenges. However, in the 1980s there was a rapid differentiation process in developing countries' economic performance. The fact that there were some winners and losers from economic globalization means that the cliché of a uniform South has almost faded away.

\section{Mandate}

The report was described by Willy Brandt in his introduction as not intended to be a technical document. This is important to emphasize and explains a large part of its impact on public opinion. Brandt also stressed the strong commitments of the members of the Commission to their mandate: "When we first met near Bonn in December 1977, we regarded it as our task to study the grave global issues arising from the economic and social disparities of the world community. And we have promised to suggest ways of promoting adequate solutions to the problems involved in development and in attacking poverty."

The Commission was strongly influenced by Brandt's vision of a new type of relationship between nations, and especially North and South. As Willy Brandt put it: "North-South relations should be seen for what they are, a historic dimension for the active pursuit of peace." The Brandt report was a major proponent of the "mutual interest" thesis which was very influential in the late 1970s: "We are looking for a world based less on power and status, more on justice and contracts; less discretionary, more governed by open rules. A start must be made in that direction, and the obvious places to start are those where positive mutual interests in change can be identified. We believe there are numerous such interests. But greater efforts are required to place them at the Centre of the debate." 19

Willy Brandt's activism and humanism is strongly present in the report. It is not surprising that once published, the report aroused worldwide attention and debates and became popularly known as the Brandt report. As he expressed it in his foreword "This report raises not only classical questions of war and peace, but also the questions of how can one defeat hunger in the world, overcome mass misery, and meet the challenge of the inequality in living conditions between rich and poor. To express it in a few words: This report is about peace."

\footnotetext{
${ }^{19}$ Brandt Commission, 1980, North-South : A Programme for Survival - Report of the independent commission on international development issues (London : Pan Books).
} 
As an independent 'commission, it was free to raise any aspects of the world situation which it considered pertinent and to recommend any relevant measures in the interest of the world economy. In pursuit of those objectives, the Commission's work had to encompass the following:

- The record of development.

- Prospects for the world economy.

- Roads to a new international economic order.

\section{Outcome and impact}

The first essential feature of the Brandt report was that it was an authoritative document aimed at creating awareness among politicians and people about the magnitude of the problem of, on the one hand, the unbalanced relationship between developed and developing countries and, on the other, the challenge of fighting against poverty and starvation. The report of the Brandt Commission North-South: a Programme for Survival was an urgent plea for change, peace, justice and jobs. It called for a fair integration of the countries of the South into the global economy. The commission expected that this would bring about needed improvements in the economic and social conditions of poor countries. At the same time, the rich countries of the North were called to share their means and power with the countries of the South.

The review of the main findings and recommendation of the Brandt report, in the light of what happened in the following years, shows how the report was well ahead of the curve. A great array of development issues for the next decades were tackled in the Brandt report, including the whole question of interdependence and mutual interests, food and hunger, economic cooperation, energy, industrialization, disarmament, world trade and the world monetary order. Highlighting current problems to be tackled urgently, it recommended an emergency programme for the next five years which was an interlocking programme requiring commitments by all parties and which was supposed to bring benefits to all.

The report provided a global perspective on developing countries' problems and underlined the interdependence between developed and developing countries and the relationship between development and world peace. It contained a number of proposals for the reform of the world economic system and concluded that such transformations would be an important contribution to a peaceful international environment and the survival of humanity.

The message of the Brandt report was that in an interdependent world, no country, whether small or big, was in complete control of its economic survival. All the countries in the North were dependent on the South and other parts of the world for raw materials, energy and for trade in general. Thus it was only if there was an acceptable pattern of trade between North and South and a fair integration of the South into the world economy that international trade could continue to prosper. Unless a certain minimum stability and fairness of the world economic system was achieved, the South would face harsh social and economic problems and finally the North would suffer and follow the South to economic disintegration. 
There were four principal elements envisaged: 1) a large-scale transfer of resources to developing countries, 2) an international energy strategy, 3) a global food programme and 4) the start of major reforms in the international economic and financial system. Apart from the publicity related to the eminent membership of the Commission, another reason for the high impact of the Brandt Report was the wide range of topics it covered and the scope of its recommendations which offered something for almost everyone.

One of its concrete recommendations was that the rich countries should increase development assistance, particularly for the less developed countries. The rich countries were to increase their Official Development Assistance to 0.7 per cent of their GNP by 1985 and to 1 per cent in 2000 (this followed the recommendation of a former independent commission of experts established in 1968 and chaired by the former Canadian Prime Minister Lester B. Pearson). ${ }^{20}$

The Brandt report also contributed to the debate on inward-oriented versus outwardoriented industrialization. It pointed out that import-substitution was good policy in the early phase of industrialization and for large countries. But it stressed also the need for more outward-oriented policies once the early phases of industrialization were reached. The report combined cautious support for export-promoting industrialization in the South with a series of recommendations to industrial countries to reduce protectionism and liberalize market access. The Brandt Commission emphasized the need for more symmetrical structural adjustment in industrial and developing countries. However, the recommendations attached to the chapter on industrialization and World trade about the need to reduce protectionism and open the market in the industrial countries remained part of an unfulfilled international agenda. Only in the 1990s through the WTO rules did things start to change in the right direction.

The report made a clear connection between armament and poverty in the developing countries. It emphasized how a world-wide disarmament could make available huge sums of money for the development of those countries. The Brandt report echoed the conclusion of a report of another group of eminent experts in the early 1960s, who had conducted a study of the economic and social consequences of disarmament. Among the 10 members of the expert group, were some of the most distinguished names in economics: Professors Oskar Lange, Wassily Leontief and Alfred Sauvy. One of the main contributions of the report was to evaluate the resources devoted to military purposes and to stress that "The most fundamental way in which disarmament affects economic life is through the liberation of the resources devoted to military use and their re-employment for peaceful purposes" and that "the promotion of economic and social development in underdeveloped countries is one of the most important ways in which the resources released by disarmament could be put in use". ${ }^{21}$ They pointed out that a much larger volume of resources could be allocated to investment for productive development in underdeveloped countries even if only a fraction of the resources devoted to military purposes were used in this way. Disarmament could thus bring about a marked increase in the rate of growth of real income in the poorer parts of the world.

\footnotetext{
${ }^{20}$ Commission on International Development, 1969, Partners in Development (New York : Praeger)

${ }^{21}$ ECOSOC, 1962, Economic and Social Consequences of Disarmament (New York: United Nations), doc. E/3593, p. 10 and 59.
} 
To conclude, the work of the commission led to a persuasive report for a new, mature kind of cooperation based on global interdependence, policy dialogue, and reciprocity between North and South. It succeeded in briefly rallying the development community because of both Brandt's personality and its distinguished panel of leaders. The Brandt Commission emphasized that global inter-dependence had became a reality and suggested a collective and responsible reply to challenges from the perspective of a kind of global Keynesianism marked by an increased North-South dialogue and cooperation. It devoted considerable thought to the question of how the South could improve its negotiating strategy. By establishing the South Commission ten years later, the developing countries did start that process of self-examination and rigorous intellectual enquiry about their place, prospects and challenges in the global economy and what they must do for themselves, as the report recommended.

However, since the publication of Programme for survival, North-South relations have deteriorated and inequality in world wealth distribution has increased significantly. The trend toward unbalanced development has become stronger, with a growing marginalization of some world regions in the global economy. Similar to the recommendations of many other such reports, especially those of Pearson's, the visionary warnings of the Brandt Commission have largely remained unheard.

The result, in terms of development assistance for example, is very depressing. The average performance in the OECD countries in 1977 was only 0.35 per cent but that level dropped to 0.24 per cent in 1998 (the share of US ODA not exceeding 0.10 per cent in 1998). Thus, the international community did not listen to these commissions' recommendations on practical solidarity in the form of development assistance from North to South.

Moreover, the Brandt report has been weak in identifying concrete measures. It has not advocated or suggested the steps for implementation and a clear sequencing to better North-South relations. The only references in the introduction by Willy Brandt to measures of implementation were:

- $\quad$ his recommendations on the need for a summit on survival, gathering world leaders from developed and developing countries to discuss the issues as a matter of urgency. It led to the organization of the Cancun Summit which was perceived as unsuccessful.

His personal appeal to a whole range of different audiences, from worlds leader to the general public, NGOs or trade unions, to read and reflect on the issues raised and to try to design appropriate responses.

At the international level, the most important initiative launched by the Brandt Commission for an effective North-South dialogue was the Cancun Summit in 1981 and the Special Session of the United Nations in New York in August 1980 where the report and its implications were extensively discussed and where there appeared to have emerged an encouraging agreement of principles on the need for a new international development strategy for the 1980s. However, blockages occurred when it came to discussing concrete and compulsory procedures to launch global negotiations between developing and developed countries and redesigning the role of the United Nations and Bretton Wood's institutions. The discussions were postponed to a near future that never came.

One of the particularities of the Brandt Commission is that it published a second report three years after A Programme for Survival. Untitled Common Crisis North-South: Cooperation for World Recovery. This 1983 report came in a context of world economic crisis with massive unemployment in the North, the threat of economic collapse in the 
South and a grave international finance crisis. The aim of the second Brandt report was to react to the deteriorating economic conditions. The sense of urgency of this report is reflected in its attempts to put forward some concrete short-term proposals to confront the so-called common crisis. It pointed out the "far greater dangers than three years ago" and forecasted "conflict and catastrophe" unless major changes in the world economic system were to take place. 22

The Brandt Commission strongly urged in this second report that the most "futuristic" of all the report's proposals regarding new sources of potential resources to support the development of developing countries should not disappear completely from view. However, they never took place in the international agenda. Later, the Brundtland Commission stated that these proposals, regarding revenue from use of international commons and natural resources, should receive serious consideration by government and the General Assembly. However, it had no more impact than the Brandt Commission.

\subsection{The Independent Commission on International Humanitarian Issues (1983-1986)}

\section{Context}

An Independent Commission on International Humanitarian Issues (ICIHI) was established in 1983 as the response of a group of eminent persons from all parts of the world to the deeply felt need to enhance public awareness of important humanitarian issues and to promote an international climate favouring progress in the humanitarian field. As a result of the world recession at the beginning of the 1980s and its social impact - in particular in the South with the multiplication of the structural adjustment programmes - there was a growing concern about the need to place human welfare at the centre of national and international policy-making and to bring humanitarian concerns to the same level of experience and expertise as is usually accorded economic and security matters.

The Commission was composed of 29 members appointed on the basis of equitable geographical representation. Its Co-chairs were Sadruddin Aga Khan and Hassan bin Talal. The Swiss Government facilitated the establishment of its Secretariat in Geneva. Zia Rivzi, a senior UN official, was detached to the Commission as director of the Secretariat and he assumed responsibility for editing the report and the various sectoral reports published under the aegis of the commission.

\section{Mandate}

The UN General Assembly supported the establishment of ICIHI. The work of the Commission was intended to form part of the continuing search of the world community for a more adequate international framework to uphold human dignity and rise to the challenge of the humanitarian problems arising with increasing frequency on all continents. The purpose of the commission was to: 1) study specific humanitarian issues

\footnotetext{
${ }^{22}$ Brandt Commission, 1983, Common Crisis, North-South : Co-operation for World Recovery (London : Pan Books)
} 
that have been inadequately dealt with to date, or call for solutions in line with new realities; 2) identify opportunities for more effective action by the international community and to make practical, action-oriented proposals that promote the well-being of people; 3 ) enhance public awareness of the conditions that create and perpetuate human suffering and 4) strengthen effort, at governmental and non-governmental level to bring about changes that will help make the world a more human place.

The commission was inaugurated in Geneva in July 1983 at the Palais des Nations in the presence of the UN Secretary-General. After inauguration, it met briefly at the Institut Henri Dunant to discuss its programme of work. Between the eight plenary sessions, several working groups were organized. Composed of members with special interest or expertise in the subject, the working groups were established to investigate various issues. They worked closely through the secretariat with the relevant academic centres as well as governmental and non-governmental international bodies. Periodically, the commission organized seminars, expert consultation, brainstorming sessions and public meetings to examine issues or to make its views known.

\section{Outcome and impact}

The commission focused on three broad areas of concern:

1) Humanitarian norms in the context of armed conflicts. Although considerable progress has been made in developing and codifying international humanitarian law, flagrant disregard of humanitarian norms persists. This reality spells heightened dangers for the victims of armed conflicts, an increasing number of whom are civilian. The aim of the commission, on one hand, was to encourage adhesion actively by government to existing international instruments and, on the other, to propose measures that deal with new problems arising out of contemporary armed conflict. For this reason, the commission suggested i) governments develop special schemes for humanitarian assistance to victims in riots, in particular women and children; ii) non-governmental bodies establish a network of local voluntary agencies specialized in programmes of community welfare, to take care of the victims; iii) United Nations, within the context of a strengthened and centralized humanitarian apparatus, designate a department or an ombudsman to monitor communal riots and the damage they cause and to help governments and non-governmental agencies to provide assistance to the victims of riots.

2) Disasters, natural and man-made. The commission selected a number of interrelated issues that are central to disaster prevention and preparedness. Particularly concerned about the destruction of the earth's resources, it focused on the humanitarian aspect of problems such as desertification, deforestation, famine as well as such human-made disasters as nuclear and industrial accidents. For each specific situation, the commission addressed recommendations in order to increase the participation of local human resources in the decision-making, promote an equitable sharing of resources between social groups and nations, develop international standards and monitoring systems to protect the safety of people, and promote the role of the $\mathrm{UN}$ as coordinator of national efforts.

3) Vulnerable groups is a term attributed to many who suffer deprivation by virtue of their status in society. The commission concentrated on the plight of only a few of the unprotected or vulnerable groups in specific situations of acute hardship: stateless, disappeared, refugees and displaced persons, indigenous population, street children and urban young. The commission's purpose was to study the problems unique to each group, the deprivation entailed, the lack of an adequate international response and the practical measures which could be taken to lessen their hardship. 
For each specific situation, the commission addressed recommendations to governments, non-governmental organizations, welfare agencies and the international community stressing the importance of respecting human rights and minimum humanitarian standards and the need to operate programmes and coordinate the activities of governmental, inter-governmental and voluntary agencies.

The ICIHI published a report "Winning the Human Race?" which contains a series of recommendations relating to the humanitarian issues. ${ }^{23}$

The report started from the concept of humanitarianism, defined as a basic orientation towards the interests and welfare of people. Humanitarianism is seen as the bridge between ethics and human rights, both of which are needed to make global society healthy and secure for present and future generations. The commission identified as humanitarian issues the elimination of poverty, the protection of the environment, the global demilitarization, the struggle against terrorism as an affront to humanity, the elimination of racial discrimination, the enhancement of the status of women, the regulation of population growth and the protection of children, minorities, refugees, displaced persons and others at risk.

According to the commission, contemporary societies are vulnerable to the action of others and all face the possibility of extinction, thus the need to formulate new standards of humanitarian decision-making is imperative. It thus stressed the need for global consensusbuilding and for strengthening multilateralism, which remains the most effective strategy to address humanitarian issues and thus promote humankind's future and well-being.

The commission recognized that main problem multilateralism faces is the reluctance of governments to interact and dialogue on issues of fundamental relevance to humankind and stated the ethical imperatives that governments should adopt in order to control and predict the consequences of their actions in a complex environment: 1) understand the full range of consequences of an action and avoid one-dimensional thinking; 2) make efforts to minimize harm and compensate the sufferers when harm is unavoidably generated in pursuit of a competing good; 3) exercise discernment in the face of unintended consequences or harm.

A realistic humanitarian strategy should be based on: 1) a set of minimum rules combining fundamental principles of humanitarian law and human rights which States and state official or soldiers would have to observe all the times; 2) ratification of 1987 Protocol I, relating to international armed conflict, which updates the means and methods of combat and provides better protection of civilian populations by a prohibition of nuclear weapons against them and 1987 Protocol II, relating to internal conflicts of a certain intensity, which provides greater protection to the civilian population, to persons deprived of liberty and to medical services and personnel; 3) observation and implementation of humanitarian norms and, in case of serious breaches, individual or collective action; 4) supplementary protection provided by the United Nations especially in situations where protection of both humanitarian law and human rights is considerably reduced; 5) increased public awareness.

\footnotetext{
${ }^{23}$ The Independent Commission on International Humanitarian Issues, 1988, Winning the Human Race (London: Zed Books)
} 
In particular, the commission recommended the international community to 1) establish a UN Central Office for Humanitarian Issues, close to the Secretary-General with the task to coordinate policies and programmes of the UN system, maximize the impact and monitor as well as provide policy guidance in regard to specific humanitarian issues; 2) articulate the linkage between international humanitarian law and the law of human rights. The concept of international humanitarian law would be broadened in order to include the Laws of Peace relating to human welfare in situations constituting a serious threat to human life, dignity and welfare and a Declaration containing the minimum humanitarian principle, based on universally accepted values common to world culture, movements and religion, should be elaborated.

The commission also recommended national governments to 1) establish an Independent National commission to look into those humanitarian issues which have remained neglected within a national context; 2) create a Ministry of Humanitarian Affairs to analyse the implication for human beings of proposed policies in the social, economic, security and other fields; 3) consider the articulation of a Right to Humanitarian Assistance which should have adequate, mutually agreed, legally binding content as to the principles and practices that should govern action in situations of humanitarian emergencies; 4) promote forms of exchange with other countries in order to develop greater understanding between people.

Finally, the commission recognized the fundamental role played by NGOs in favour of humanitarian issues and recommended cooperation within and among countries through their networks at regional and international level as a vital factor for the promotion and strengthening of multilateralism as well as international understanding.

The commission also published several sectoral reports, containing greater details for those who may be interested in famine, deforestation, street children, modern wars, disappeared, refugees and displaced persons and indigenous population. ${ }^{24}$

Finally, it decided at the outset that in order to reach and influence a wide public around the world, it would be necessary to use the media, particularly television. A series of eight short TV programmes, entitled Humanitas, destined for Third World networks, had been designed to cover selected humanitarian issues, as support material to its reports and recommendations.

${ }^{24}$ Such as Famine: A Man-Made Disaster? (London: Pan Book, 1985), Modern Wars: The Humanitarian Challenge (London: Zed Books, 1986), The Vanishing Forest: The Human Consequences of Deforestation (London: Zed Books, 1986), Street Children: A Growing Urban Tragedy (London: Weidenfeld and Nicholson, 1986), Refugees: The Dynamics of Displacement (London: Zed Books, 1986) or Indigenous Peoples: A Global Quest for Justice (London: Zed Books, 1987) 


\subsection{The Brundtland Commission (1984-1987)}

\section{Context}

The commission was established at a time of unprecedented awareness on global environment issues. Also, during the time of the work of the commission, major tragedies took place - such as the African famines, the leak at the pesticide factory at Bhopal and the nuclear disaster in Chernobyl - that have strengthened the will of the commission to recommend major global changes on poverty and malnutrition.

At the same time, the large-scale implementation of structural adjustment programmes in developing countries was marked by a retreat from the social dimension in policy-making and the supremacy of economic issues. It took place in a very difficult period for most of the developing countries that faced poor economic performance and deteriorating social conditions together with increasing poverty and a deterioration of basic health and education services.

The independent World Commission on Environment and Development was established by the United Nations General Assembly resolution 38/161 in 1983 with the objective of analysing environmental and human development issues and to make recommendations for a global agenda for change.

The UN Secretary General called upon Gro Harlem Brundtland to establish and chair the independent commission because "no other political leader had become prime minister with a background of several years of political struggle, nationally and internationally, as an environment minister". ${ }^{25}$ Mrs Brundtland had a free hand in putting together a team and with the help of her vice-chair - Dr Mansour Khalid, former foreign minister of Sudan she selected the 23 eminent political figures and experts in environment and development from developing and developed countries who composed the commission.

\section{Mandate}

The mandate was officially adopted at its Inaugural Meeting in October 1984 in Geneva: 1) to re-examine the critical environment and development problems in the world and to formulate realistic proposals to solve them;2) to strengthen international cooperation on environment and development, to assess and propose new forms of cooperation that can break out of existing patterns together with the ability to influence policies and events in the direction of needed change; and 3) to raise the level of understanding and commitment to action on the part of individuals, voluntary organizations, businesses, institutes and governments.

Establishing the links between poverty, inequality and environmental degradation formed a major theme of the Brundtland Commission analysis and deeply influenced its recommendations. It emphasized the need to reach a new era of economic growth which would be socially and environmentally sustainable. The commission aimed to re-examine the environment and development problems facing the world through a new analytical framework, considering them as one common challenge to be solved by collective multilateral action. This holistic perspective of these common concerns led logically to the

\footnotetext{
${ }^{25}$ The World Commission on Environment and Development (The Brundtland Commission), 1987, Our Common Future (Oxford: Oxford University Press), p. ix-x.
} 
proposal to create a "global agenda for change". From the beginning, Mrs Brundtland linked the work of her commission to the precedent work of the Brandt Commission and the Palme Commission on which she served. She aimed at formulating a third and compelling call for political action on what would become the report, Our Common Future.

\section{Outcome and impact}

Published in 1987, one of the goals of the report, Our Common Future, was "to help define shared perceptions of long-term environmental issues and the appropriate efforts needed to deal successfully with the problems of protecting and enhancing the environment, a longterm agenda for action during the coming decades, and aspirational goals of the world community" ${ }^{26}$ It suggested that the objectives of social equity, economic growth and protection of the environment were simultaneously possible as long as a sustainable development approach was taken that there was a redistribution of resources toward poor countries and a promotion of technological and social changes.

The report highlighted the interactions between problems facing the world and proposed a common approach to peace, security, development and the environment. It emphasized eight major international goals:

- Revival of economic growth

- Improvements in the quality of growth, ensuring environmental and social soundness and meeting needs for employment, food, energy, water and sanitation

- Conservation and enhancement of the natural resource base

- Stabilization of population levels

- Reorientation of technology and improved risk management

- Integration of the environment and economics into decision-making processes

- Reform of global economic relations

- Strengthening of international cooperation

The Brundtland report brought the issue of sustainable development to the forefront with the publication of Our common future. It gave a thorough survey of the major global environmental crisis and challenges but also made some concrete proposals concerning how those problems could be resolved. The report alerted the world very successfully to the urgency of making progress toward some patterns of economic development that could be sustained without harming the environment and creating social tensions.

The report has also greatly contributed to the popularization of the notion of sustainable development. The concept of "sustainable use" had been suggested before in 1980 by the International Union for Conservation of Nature and Natural Resources (IUCNNR), the United Nations Environmental Program (UNEP) and the World Wildlife Fund (WWF) in their World Conservation Strategy. However, the Brundtland Commission transformed it from a purely ecological approach to a more socio-economic one where development is to be distinguished from growth and quality aspects of development are as important as quantitative aspects. It was responsible for the now famous definition of sustainable development that became the cornerstone of all the thinking on development and the

\footnotetext{
${ }^{26}$ p.ix
} 
environment. The definition of sustainability proposed by the Brundtland Commission has greatly contributed towards some degree of acceptance of what it means, what is required to pursue it and the measures that countries should adopt to put it into practice. The report refers to sustainable development as development "that meets the needs of the present generation without compromising the ability of future generations to meet their own needs". The report highlighted three fundamental components to sustainable development: environmental protection, economic growth and social equity.

The report also made some institutional and legal recommendations for change in order to confront common global problems. It called in particular for the development and expansion of international institutions for cooperation, legal mechanisms to confront common concerns and for increased cooperation with industry. The Brundtland report put forward 22 new legal principles to help achieve sustainable development, recommending that these principles be incorporated into national laws or charters that specify the rights and duties of citizens and States, and into a world convention on the sovereign rights and responsibilities of nations.

The report also stressed the need to dedicate huge financial resources to support the repair of environmental damage, control pollution and invest in sustainable development. To support that aim it suggested some innovative solutions such as levying taxes on the use of global commons and on revenues from seabed mining and ocean fishing.

This report became one of the seminal environmental documents of the $20^{\text {th }}$ century. It was representative of the growing global awareness related to environmental issues that had emerged in Stockholm in 1972 with the organizing of the UN Conference on the Human Environment. It succeeded in capturing widespread interest in environment and poverty issues in many parts of the world. Through the concept of sustainable development, it had a profound impact on the way in which political leaders, business and civil society representatives perceived the earth and development policies.

The Brundtland report was an important step in a process which started in 1972 with the Stockholm Conference on Human Environment, continued at the UN Conference on Environment and Development in Rio in 1992 and the September 2002 UN Conference on Sustainable Development. Over the years, this process has transformed concerns about environment and development into significant and far-reaching concepts, and has turned those concepts into action.

In that process, the Brundtland Report played a key role, not so much for what it brought to the debate in terms of value added - notwithstanding its successful and concise definition of sustainable development - but for the reaction it has stimulated. It has had a great impact on the international agenda at a crucial time. Because the commission was able to build a large political consensus around the final document, sustainable development became a political issue.

Clearly, the Brundtland Report achieved its purpose, which was to create awareness about environmental and development issues. It got people talking about sustainable development, writing about it in the hundreds of articles and books that have been published on the topic. Sustainable development has become an integral part of the policy discourse of many international and national organizations. ${ }^{27}$

${ }^{27}$ David Brooks, 1990, "Beyond catch phrases: What does sustainable development really mean", IDRC Reports, October, p.24-25. 
This is a landmark report that has helped trigger a wide range of actions, including the Rio Summit, the International Climate Change Convention, the Agenda 21 programme and the Johannesburg summit. The Rio Declaration, for example, was deeply related to the Brundtland Report when it firmly established the inherent link between environmental issues and development, stating in its principle 4 that "in order to achieve sustainable development, environment protection shall constitute an integral part of the development process and cannot be considered in isolation from it".

There is now a strong consensus about the need to design integrated development policies including the economic, social and environmental dimensions. Decision-makers largely acknowledged that sustainability requires making decisions that recognize the connection between action and effects in the environment, economy and society. From this perspective, the concept of sustainability led to new evaluation criteria for development projects and programmes taking into account the potential collateral damage to the environment that could be associated with the implementation phase and their long-term impact on the ecosystem. The concept of sustainable development has been further developed within the UN system which tends to use the terms: "sustainable human development" and "sustainable economic development".

In the final chapter of its report, the Brundtland Commission called for an international conference to be convened in order to review progress and create a follow-up structure. This conference, the UN Conference on Environment and Development (or Earth Summit), was held in June 1992 in Rio. It brought together the heads or senior officials of 179 governments and was at that time the largest ever meeting of world leaders. The Earth Summit produced two international agreements and a major action agenda called Agenda 21 , a 300-page plan for achieving sustainable development in the $21^{\text {st }}$ century. The Commission on Sustainable Development was also created after the conference. It meets once a year to carry out in-depth discussions and review major sustainable development issues.

\subsection{The South Commission (1987-1990)}

\section{Context}

The impressive social and economic gains experienced by many of the countries of the South in the period following the end of the Second World War until the end of the 1970s, gave rise to the expectation that the North-South divide in wealth and power could be bridged. The 1980s belied that expectation. While the industrial countries recovered from the recession of the early 1980s and by 1990 had enjoyed seven years of uninterrupted growth, most countries of the South faced an acute and continuing development crisis. This crisis was mainly the outcome of adverse turns in the world economy, which developing countries were powerless to control. The South's setbacks were largely the product of the contradictory policies followed by the industrial countries and the sudden drying-up of capital flows. The adjustment policies imposed on many developing countries by international financial institutions intensified deflationary pressures and added to the hardships.

The plan to establish the South Commission was announced at the $8^{\text {th }}$ Meeting of the Heads of State and Government of the Non-Aligned Countries held in Harare, Zimbabwe, in September 1986 by Dr. Mahathir Bin Mohamad, Prime Minister of Malaysia. Dr. Mahathir had headed a steering committee, which had been set up at an international meeting held in Malaysia to make the preliminary arrangements for the formation of the commission. 
The South Commission was an independent body, with 27 commissioners serving in their personal capacities. Its term was set for three years. Julius K. Nyerere, former President of Tanzania, was the Commission's Chair. Staff of the commission included a SecretaryGeneral (Mr. Manmohan Singh), a Senior Professional Staff, a Chairman Professional Staff and a General Service and Support Staff.

The South Commission was to respond to the need of the nations of the developing world to confront the economic, social and political challenges of the $20^{\text {th }}$ century. In particular the mandate included the analysis of: 1) national development experiences in the South and elaboration of an integrated perspective and vision of the future; 2) the global environment; 3) South-South cooperation for collective self-reliance and 4) South-North relations. In addition, the commission was asked to provide a strategy and a set of policy and actionoriented proposals that stem from the South and were based on the needs of the South.

\section{Outcome and impact}

The South Commission adopted an integrated approach to the challenges faced by developing countries. It took account of the interrelated nature of the problems which face them, linking together matters of national development, South-South cooperation, NorthSouth relations and the global system.

The vision of the South Commission for the South was to achieve a people-centred development: a form of development that is self-reliant, equitable, participatory and sustainable. It approached the problems of the South from the point of view of the South, although it recognized that South interests are not to be in permanent conflict with those of the North, or that the suggested self-reliance must imply a turning away from the rest of the world.

They acknowledged that development requires sustained economic growth in order to eradicate poverty, but priority should be given to policies aimed at ending poverty, increasing productive employment and ensuring that the basic needs of all people are met, with any surplus being fairly shared. All services and goods - such as food, shelter, basic education and health facilities - should be accessible to all and without discrimination. The commission also included a democratic form of government, together with its supporting of individual freedom of speech, organization and information, as well as an effective system of justice, which protects all people from actions in breach of just laws, which are known and publicly accepted.

The agenda of action the South Commission proposed for the South was divided in three parts: 1) domestic policy within a national setting; 2) the imperatives of collective selfreliance and 3) solidarity as equally essential for improving the South's position within the world system of economic relationships.

The report The Challenge to the South was the result of three years of deliberation and work of the commission. ${ }^{28}$ At its last meeting in Arusha, the commission decided that a companion volume of commentaries on its report - Facing the Challenge - should be prepared. By giving renowned individuals, experts and political figures concerned with development the opportunity to comment publicly on the report, the commission felt that its work could be supplemented and expanded.

\footnotetext{
${ }^{28}$ The South Commission, 1990, The Challenge to the South (Oxford: Oxford University Press).
} 
The report indicated the principles and objectives that need to guide the development courses of all countries and show how developing countries could gain strength and bargaining power. From a national perspective, the South should pursue a self-reliant and people-centred development strategy, which implies that satisfying basic needs should have priority, both on the grounds of equity and to sustain economic growth at a rapid pace. People-centred development also requires democratic structures and institutions, appropriate to the culture and history of each country.

The commission has recommended a set of broad economic objectives designed to meet people's needs through a development process that combines high rates of growth with equity while being, at the same time, environmentally sound: 1) satisfying food security; 2 ) investing in human resources by achieving universal health care, education and sanitation; 3) implementing a rapid pace of industrialization in order to achieve high rates of economic growth, generate employment and raise income; 4) closing the knowledge gap; 5) reviewing the respective role of the State and of market forces in development; 6) supporting the business sector; 7) giving priority to the raising of the social and economic status of women; 8) promoting the cultural roots of the society and culture; 9) adopting an integrated environment-sensitive approach to development.

According to the commission, South-South cooperation could fortify the development of all countries of the South. As a contribution to the formulation of a comprehensive approach to South-South cooperation, the commission selected several priorities: 1) finance and an equitable solution to the debt problem with debt servicing reduced to levels that allow economic recovery; 2) offering a framework for expanding trade by lowering tariff and non-tariff barriers and reducing the dependence on markets and suppliers in the North; 3) promoting investments and stimulating agricultural and industrial production; 4) developing the service sector; 5) improving food output and security; 6) narrowing the knowledge gap in science and technology with the North and building up capabilities in applying the advances of science to its development needs; 7) protecting the environment; 8) strengthening the communication and information exchange and 9) promoting forms of sub-regional cooperation.

Sustained development in the South necessitated a fundamental restructuring of the international economic system, which covers the international financial, monetary and trading system (North-South relation and the international system). The commission suggested a Six-point Global Programme of Immediate Action of 1) stopping the net transfer of resources form the South to the North; 2) reforming the international trading system by giving priority to improving the access of developing countries to markets of developed countries; 3) doubling the volume of concessional resource transfers to developing countries, priority being given to transfers through multilateral institutions; 4) establishing independent international mechanisms to evaluate the requirements of developing countries, the norms and indicators for performance and the criteria and conditionality appropriate to each country; 5) lifting protectionist barriers to developing countries' exports to the developed countries; 6) incorporating contingency provisions in international arrangements in order to protect developing countries against excessive fluctuations in international interest rates, exchanges rates and terms of trade. 
In conclusion, the South should harness all its energies for the following tasks:

- A fundamental reshaping of its economies, politics and societies leading to institutional structures and value systems which prize creativity, innovation and a spirit of enterprise as well as a deep concern for social justice;

- The mobilization and enhancement of the potential of the people through the pursuit of development strategies and patterns which put the people at the centre and aim at raising the quality of life for all;

- An effective population policy, based on a vigorous social development strategy;

- A long-term commitment to rational and prudent management of the environment and use of scarce natural resources, particularly land and water.

The commentaries in Facing the Challenge were positive (Pisani, Kothari, Sewell and Melcher, Mistry, Islam, Strong) and recognized the efforts undertaken in terms of research and analysis (Galbraith, Galtung, Seyyid Abdulai, Amin, Camdessus, Conable, Dadzie, Goldenberg, Gunatilleke). ${ }^{29}$ It is interesting to note that the South Commission increased expectations to see the debate furthered and improved with more ideas and that many of these expectations have been disappointed. Some experts (Comeliau, Wallerstein) complained that the report offered no new vision, no new bases and no fresh practical proposals to the analysis of the situation and to the political options that this requires. Some others complained about poor attention to gender issues (Pietilä).

The South Commission advocated an equitable solution for the debt problem (reduction of debt of developing countries), stating that developing countries - and in particular less developed countries - will never be able to repay in full their external debt and some appropriate financial mechanisms should be adopted to reduce the burden of highly indebted countries. The commission also advocated opening international markets to the products of developing countries and complained about the high protectionism affecting exports of processed products and manufactures of the South. Since the publication of the report, there has been some major trends toward the recommendations of the South Commission through the worldwide implementation of WTO rules and the growing concern of the G8 regarding the debt problem.

\subsection{The Independent Commission on Population and Quality of Life (1991-1996)}

\section{Context}

The fifty years after World War II saw a spectacular growth in population. Even if population growth stabilizes by 2040 , it will continue to grow for several decades; this demographic transition will imply more than 4 billion people between now and 2050. Of the global population, 16 per cent live in the industrialized countries; about 45 per cent of the population in developing countries is below the age of 15 and the number of older people is rising everywhere from its current level of 10 per cent. At the same time, global product has more than quadrupled in real terms, imposing serious strains on natural resources and triggering pollution, poverty and famine.

\footnotetext{
29 The South Commission, 1993, Facing the Challenge: Responses to the Report of the South Commission (London: Zed Books)
} 
The high expectations for peace did not materialize and the importance claimed by defence security tended to neglect other elements of human security relating to food, health, employment and income and the environment. All these factors are integrally part of the tensions represented by the processes of global transition.

The world's survival requires unprecedented, collaborative solutions that unite all nations in a shared commitment to adapt production and consumption patterns as well as addressing population issues in a way that fosters equitable development and respect rights.

In this context, the Independent Commission on Population and Quality of Life (ICPQL) was launched at the initiative of several organizations working in the population field, to promote both a vision and immediate, concerted action that recognizes and builds upon synergetic among all actors in the population/family planning fields and programmes.

\section{Mandate}

The mandate of the commission implied 1) searching for a "fresh vision" on population issues that would include all the factors interacting with population and in their interfaces; 2) listening to the broadest possible audience and trying both to gather data from their experiences as well as disseminating its own vision on the issues raised.

The commission was an independent body, with 18 members and one president, Maria de Lourdes Pintasilgo. Staff of the commission included an Executive Secretary (Pierre de Senarclens), a Senior Staff Adviser (Stafford Mousky), several population, gender, human resources and development specialists, several consultants and administration, communication and support staff.

Two preparatory meetings were held before the commission was finally created:

- London, 3 December 1991: This meeting aimed to assess the population and familyplanning situation worldwide, define new opportunities for both and identify constructive ways to take advantage of the opportunities. The principles governing the organization of the commission and its composition were also agreed upon;

- Bellagio Study and Conference Center, 4-5 March 1992: This meeting constituted proffered names of potential candidates for the Chair, defined the functions and the composition of the secretarial staff and considered the need to raise funds besides those already committed by governments and institutions whose representatives were present at the preparatory meetings.

The commission met every six months for three years. As a consequence of the decision taken at the second session to give priority in its approach to the people and representatives of institutions directly involved at the grass-roots level with population issues, a series of Public Hearings was organized in seven different regions of the world: Southern African Public Hearings at Harare (Zimbabwe), 10-11 December 1993; Western Africa Public Hearings at Bamako (Mali), 22-25 February 1994; North-America Public Hearings at Washington (DC), 28-30 March 1994; South Asia Public Hearings at New Delhi, 25-27 April 1994; Latin America Public Hearings, 14-18 August 1994; South-Asia Public Hearings at Manila, 20-23 September 1994; Eastern Europe Public Hearings at Moscow, 17-24 October 1994. Within the public hearings the commission consulted experts on population issues and specialists from a broad spectrum of disciplines. Two thematic panels were organized in addition to direct consultation with individuals: 
- Population Policies and Governance, Bellagio, 27-30 September 1993: considering the evolution of population policies and measures adopted by different countries in the second half of the 20th century and analysing the interconnections with governance and ethics;

- Production and consumption patterns in relation to the Earth's carrying capacity and their impact on the quality of life, Stockholm, 18-20 May 1994: presenting and analysing possible strategies to modify current production and consumption patterns, taking into account ethical and environmental concerns.

Finally, a series of topical papers contributed by a broad array of specialists commissioned from around the world gave state-of-the-art data and views on population studies (some of them of a cross-regional nature) and quality-of-life concerns.

\section{Outcome and impact}

The debate of the commission basically focused on two key concepts:

- Population: Population implies people and numbers. People are too often forgotten in favour of abstract, macroeconomics targets. If population is considered in number alone, isolated from the other aspects of life, this is wrong in both human and scientific terms. Thus, a balance is needed;

- Quality of life: Once the threshold of quantity (beyond the level of mere survival) is crossed, it becomes the guiding principle in regard to sustainable consumption. It emerges as a combination of rights and duties, as clear indications both for decisionmakers and the dynamic components of civil society. Secure enjoyment of health and education, adequate food and housing, stable and healthful environment, equity, gender equality, participation in everyday life and dignity and security - much of what people call their quality of life is culturally defined, so the notion itself may always retain an element of subjectivity and cultural diversity.

In learning and reflecting the experience and views of concerned groups and individuals in governments, multinational and non-governmental organizations, the commission recognized that a common ground must be developed among multiple constituencies to promote harmonious action and generate the necessary support, including increasing the financial resources available. The commitments of governments must be strengthened to formulate policies and both governments and NGOs must improve their institutional and technical capacities to implement programmes deriving for these policies.

The commission also kept in mind the need to focus on individual, on the family and on the capacity of individuals and couples to realize its own reproductive objectives in all population policies and programme to achieve, on the one hand, individual freedom and better conditions for the family and, on the other, a sustainable growth-rate of population. Reproductive choice, sustainable population growth and size and the rights of women are essential elements in a broad strategy of development.

The main result of the ICPQL is the report Caring for the Future, in which the commission outlined its vision with the purpose of stimulating action among people, enterprises, the scientific community and activists. ${ }^{30}$

${ }^{30}$ The Independent Commission on Population and the Quality of Life, 1996, Caring for the Future: Making the Next Decades Provide a Life Worth Living (Oxford: Oxford University Press) 
The commission reflected the report of the Brundtland Commission (1987) in linking the questions of population - population pressure and human rights - to poverty, environment and development. It also referred to the Cairo Conference (1994), which pointed out that population growth adds to poverty projections.

The commission advocates a more holistic approach to promote quality of life for populations, proposing that the concept of sustainable improvement in the quality of life become the central focus for policy-making in all countries. Based on a comprehensive approach, sustainable improvement in the quality of life is reached through: i) meeting the basic, minimal survival needs of the population since a certain, minimal quantity is essential before there can be meaningful quality of life (enhancing human security); ii) focusing on sustainability in economic terms (keeping the stock of natural capital intact) and in social terms, by allowing human beings to develop their personalities through health and education; iii) focusing on rights and responsibilities; iv) the involvement of civil society, people's participation, international organizations and institutions.

According to the report, in order to ensure the quality of life, governments must face several challenges and for each of them the ICPQL suggested a strategy:

- Population challenge: According to the commission, a new understanding of population is needed. Policies based on population as numbers cannot overlook their primary goal, improving the quality of life of population as people. This implies 1) the adoption of a comprehensive health policy, which includes voluntary familyplanning programmes and prevention measures and 2) the empowerment of women as a new social force;

- Social challenge: Population growth deepens poverty and can lead, combined with laws and inheritance issues, to a fragmentation of land-holdings and living below subsistence levels. Although it is usually seen as the cause of poverty, demographic growth is only one of the reasons for the persistence of poverty. The report advocated an improved security for a more liveable world by: i) promoting human security (achieving minimal quality-of-life standards in health care, education, housing) and higher standards once the minima are attained; ii) universalizing the four existing treaties embodying a range of human rights relevant to the quality of life (the Convention on the Elimination of Discrimination against Women, the Convention on the Rights of the Child, the International Covenant on Economic, Social and Cultural Rights and the International Convention on Civil and Political Rights) and iii) setting targets and performance indicators;

- Ecological challenge: Policy and practice of conservation and efficiency are the new imperatives for the survival of the environmental capacity to support human life. This will require, among other changes, strict regulation of industrial activity and the ecological harmonization of the patterns of human settlement, making population the flexible factor (as environmental impact in the past was made the disposable factor). At the same time, keeping food production in step with population growth and consumption is crucial, especially for the escalating poor;

- Economic challenge: The commission advocated for a new economic revolution in that economy based on quantity must make way for economy founded on quality, producing quality goods and more and better services, ensured by quality labour (education and vocational training). Production schemes and consumption patterns 
must change, by i) developing a macroeconomic framework for the long-term consequences of economic activity and ii) reorienting the functioning of economies by questioning and adapting current production processes as seen through their impact on the environment. The commission proposed to redefine work in a broad sense, encompassing a wide spectrum of activities (conventional employment and unpaid activities benefiting society at large) and emphasizing families and individuals and an equitable distribution of the wealth thus generated.

\subsection{The Commission on Global Governance (1992-1995)}

\section{Context}

The establishment of this commission was strongly influenced by the new global vision that there was no alternative to working together and using collective power to create a better world. Thus the world community should assume greater collective responsibility in a wide range of areas such as military, social and economic security, sustainable development, the promotion of democracy, equity and human rights, humanitarian action, and the reduction of inequality in world income distribution.

The goal was to make some proposals for global governance in the post-Cold War era that is characterized by democratization, the growing voice of civil society, greater interdependence, an emerging global world and widening inequalities between and within countries. How are people going to manage human affairs in these and other fields of global endeavour to respond satisfactorily to the challenge of survival? The need for global governance was strengthened by major events (ethnic cleansing in the Balkan, the war in Somalia and genocide in Rwanda) that occurred during the span of the commission.

\section{Mandate}

Early Willy Brandt saw the importance of taking some political action on global governance to face major challenges that could be met only through coordinated multilateral action. His initiative in January 1990 convened in Königswinter, Germany, the members and senior staff who had served on the North-South Commission (the Brandt Commission), the Independent Commission on Disarmament and Security Issues (the Palme Commission), the World Commission on Environment and Development (the Brundtland Commission), and the South Commission (chaired by Julius Nyerere). The meeting's outcome was that the participants asked Ingvar Carlsson (then Prime Minister of Sweden), Shridath Ramphal (then Commonwealth Secretary-General), and Jan Pronk (Minister for Development Cooperation of the Netherlands) to prepare a report on the opportunities for global cooperation on issues requiring multilateral action.

Following this group's report, some three dozen public figures met in Stockholm in April 1991 to discuss the needs of the 1990s. In the Stockholm Initiative on Global Security and Governance they proposed that an international commission be set up to explore the opportunities created by the end of the Cold War to build a more effective system of world security and governance. Willy Brandt, after consulting Gro Harlem Brundtland and Julius Nyerere, invited Ingvar Carlsson and Shridath Ramphal to co-chair the proposed commission. In April 1992, the co-chairs met UN Secretary-General BoutrosGhali to explain the purpose of the commission, who commended the initiative and assured them of his support. 
By September 1992, the commission was established with 28 members from all around the world; with only one whose background was not dominated by government service. This fact did not signal a significant attempt at giving a voice to the civil society, which was contrary to the proposals of the commission to involve NGOs, citizens' movements or transnational corporations.

Its mandate was strongly influenced by Willy Brandt's vision of a global neighbourhood with political, economic and social rights for all people. The commission's basic aim was to contribute to the improvement of global governance. It had to analyse the main forces of global change, examine the major issues facing the world community, assess the adequacy of global institutional arrangements and suggest how they should be reformed or strengthened.

Former commissions had addressed specific areas of global affairs: Brandt had dealt with development, Palme with security, Bruntdland with environment, Nyerere with the South. All had a bearing on the issue of survival and their recommendations in substantive policy areas still commanded attention. For that reason, it was stressed that the commission should be able to draw on the work of the previous independent commissions chaired by Willy Brandt, Olof Palme, Sadruddin Aga Khan and Hassan bin Talal, Gro Harlem Brundtland, and Julius Nyerere. The central task of the commission was then to suggest how world governance could be developed and improved to enlarge the probabilities of success.

From this perspective, the commission's terms of reference, adopted at its third meeting in February 1993, were as follows: "The Commission on Global Governance has been established at a time of profound, rapid and pervasive change in the international system - a time of uncertainty, challenge and opportunity. Five decades after World War II and in the aftermath of the Cold War, a new world is taking shape. It could give new meaning to the common rights and responsibilities of nations, peoples and individuals. It could bring greater peace, freedom and prosperity. The commission has been established to contribute to the emergence of such a global order."

\section{Outcome and impact}

In January 1995 the commission published its report Our Global Neighbourhood. In the kind of world that globalization and technological change were creating, the commissioners were under no illusion that it was a wholly benign neighbourhood or that it was cohesive, integrated or secure; the title reflected the reality of a human community and embodied hope for a neighbourhood evolving in worthier ways - to which global governance had much to contribute. ${ }^{31}$ The title also echoed the new conventional wisdom that people now lived in a global and interdependent world.

Published at the start of the UN's $50^{\text {th }}$ anniversary, the commission's recommendations focus principally on the United Nations, the only forum in which governments come together regularly to tackle world problems. Our Global Neighbourhood suggests how the UN should be revitalized so it can better respond to the needs of the modern world - a world that has changed in many ways since the UN was formed in 1945. From this perspective, the Commission on Global Governance has attached critical importance to the

${ }^{31}$ Security in the Global Neighbourhood, The Second Global Security Lecture by Sir Shridath Ramphal, Co-Chairman, The Commission on Global Governance, University of Cambridge, June 1995. 
reform of the Security Council and to taking into account the emergence of a global society.

The report called for a shift in the vision of global governance to include civil society organizations, TNCs, academia and the mass media. It made clear that global governance was not global government, but "the sum of the many ways individuals and institutions, public and private, manage their common affairs. It is a continuing process through which conflicting and diverse interests may be accommodated and cooperative action may be taken".

The report included proposals to:

- Reform the Security Council, so that it becomes more representative and maintains its legitimacy and credibility

- Set up an Economic Security Council to have more effective - and more democratic - oversight of the world economy

- Establish a United Nations Volunteer Force so that the Security Council can act more quickly in emergencies

- Vest the custody of the global commons in the Trusteeship Council, which has completed its original work

- Treat the security of people and of the planet as being as important as the security of States

- Strengthen the rule of law worldwide

- Give civil society a greater voice in governance

- Explore ways to raise new funds for global purposes, e.g. a tax on foreign currency movements, and charges for using flight lanes, sea-lanes and other common global resources.

The report endorsed some of the new thinking on development aid, both in terms of quantities and in terms of impact. It emphasized the need for more resources and pointed out that only a few countries had met the target of 0.7 per cent of their GDP for development assistance (an objective stressed by the Pearson, Brandt and Brundtland commissions).

An important intellectual contribution of the report was related to its work in broadening the security concept. The commission concluded that the time had come to establish global governance arrangements that respond to threats to the security of people and suggested that "a global consensus exists today for a UN response on humanitarian grounds in cases of gross abuse of the security of people". However, there are countervailing factors. Article 2.7 of the UN Charter expressly forbids the United Nations from intervening in matters "essentially within the domestic jurisdiction of any State".

The commission called for an adaptation of the principles of sovereignty and nonintervention in ways to recognize the need to balance the rights of States with the rights of people, and the interests of nations with the interests of the global neighbourhood. It proposed a UN Charter amendment to permit interventions based on humanitarian grounds but restricting it to cases which in the judgement of a reformed Security Council constitute violation of the security of people so extreme that it requires an international response. 
The commission developed its ideas and proposals on global security to reflect the transition from a world of States to a world of people, from the conventional security of countries to the security of people worldwide. This encompasses not only the insecurities of war and repression, but also the chronic insecurities that afflict the hungry, the homeless, the destitute, the unemployed, those who are ill without healthcare, those who are cold without heating, and those who are old without social support.

Inspired by one of the members of the commission, Jacques Delors, the commission proposed the establishment of an Economic Security Council within the UN system to give political leadership and promote consensus on international economic issues where there are threats to security. The permanent members of the Security Council did not show any enthusiasm over the proposal and no action was taken.

The commission advocated that it was time to establish an Economic Security Council as an apex global economic body within the UN system but reaching beyond governments. Its essential function would be to continuously assess the overall state of the world economy and the interaction between major policy areas; provide a long-term strategic policy framework in order to promote stable, balanced and sustainable development; and secure consistency between the policy goals of the major international economic organizations, particularly the Bretton Woods institutions and the World Trade Organization.

Our Global Neighbourhood was commended by world figures such as Nelson Mandela, Gro Harlem Brundtland and Vaclav Havel. World-wide interest led to its appearance in 15 languages. This book-length report still animates much of the internationalist literature. It was neither the first nor the last report to stress the need to find better ways of handling global problems, but it did an unusually effective job of conceptualizing the practice and challenges of global governance.

Thus the commission has helped to place governance on the world's political and intellectual agenda and to widen the ranks of citizens who want to improve the way the world manages its affairs. Its call for a greater role for civil society has resonated widely.

2.8 The World Commission on Culture and Development (1992-1995)

\section{Context}

In January 1988, as Secretary-General of the United Nations, Javier Pérez de Cuéllar joined Federico Mayor, Director-General of UNESCO, in launching the World Decade for Cultural Development (1988-1997). At its Twenty-sixth session in 1991 the General Conference of UNESCO adopted a resolution requesting the Director-General, in cooperation with the UN Secretary-General, to "establish an independent World Commission on Culture and Development comprising women and men drawn from all regions and eminent in diverse disciplines, to prepare a World Report on Culture and Development and proposals both for urgent and long-term action to meet cultural needs in the context of development.". This request was endorsed by a resolution adopted by the UN General Assembly. In November 1992, Boutros Boutros-Ghali and Federico appointed Javier Pérez de Cuéllar as President of the commission, comprising 14 members and 5 honorary members (four of the latter were Nobel laureates Aung san Suu Kyi, Ilya Prigogine, Derek Walcott, Elie Wiesel). 
Culture was increasingly evoked, even if not often explicitly, by several distinguished groups: the Brandt Commission, the South Commission, the World Commission on Environment and Development and the Commission on Global Governance. The idea of a WCCD was inspired by the process, from the Brundtland Report to the Rio Summit and beyond, which led to the conviction that culture and development need to be jointly analysed. The commissioners felt that the time had come to do for "culture and development" what had been achieved for "environment and development". It intended to face the challenge of building cultural insights into the broader development strategies, as well as a more effective practical agenda, as a further step in rethinking development.

The mandate focused on identifying, describing and analysing basic questions, concerns and challenges related to: a) the cultural and socio-cultural factors that affect development; b) the impact of social and economic development on culture; c) the interrelatedness of culture and models of development; d) the ways in which cultural development, and not only economic conditions, influence individual and collective well-being; e) the cultural sector as such and as an important area for development and for international cooperation.

Although such interactions between culture and development have long been recognized as essential, there was no worldwide comparative analysis on which new policies could be based. UNESCO and the United Nations provided the secretariat of the commission.

\section{Outcome and impact}

In November 1995, the President of the commission, Mr Javier Pérez de Cuéllar, presented the report, Our Creative Diversity, to the General Conference of UNESCO and the UN General Assembly.

Under its opening rubric, "development divorced from its human or cultural context is growth without a soul", the report argued for a new approach. Far from culture being merely an instrument which helped or hindered the process of economic development, the commission advanced the view that "economic development in its full flowering is part of a people's culture".

The report analysed the relation between culture and development. "We want it to capture the attention of the world's intellectual and artistic communities, as well as the general public." It addressed the key issues of

- Global ethics;

- Pluralism;

- Creativity and empowerment;

- Gender, children, young people and culture;

- Cultural heritage for development;

- Culture and environment;

- Rethinking cultural policies. 
Our Creative Diversity was an urgent call for the widest possible democratic mobilization. Poverty, unemployment, hunger, ignorance, disease, squalor, and exclusion are problems reinforced by cultural habits that lead to narrow selfishness, prejudice and ill-advised hatred.

According to the report, any policy for development should be profoundly sensitive to and inspired by culture itself. In addition to the urgent call to eradicate poverty, WCCD expressed the need to reformulate cultural policies in general and the need to generate and monitor knowledge on the links between culture and development. The report also underlined the concept of cultural freedom, a collective freedom referring to the right of a group of people to follow a way of life of its choice. Cultural freedom, by protecting alternative ways of living, encourages creativity, experimentation and diversity, the very essential of human development.

In this spirit, the commission formulated an International Agenda that recommended a shortlist of actions that could help in promoting change and adjustment without compromising the valuable elements of communities. These actions seek to:

- Enhance and deepen the discussion and analysis of culture and development;

- Foster the emergence of an international consensus on culture and development, particularly through the universal recognition of cultural rights, and of the need to balance these rights with responsibilities;

- Ensure that through the advance of human development, wars and internal armed conflicts can be reduced;

- Apply the balance of rights and duties to the media of communication;

- Initiate a process of capsulation that will lead to a Global Summit on Culture and Development;

- Promote the widest democratic participation by all, especially women and young people;

- Promote this participation at all levels, from the local, the provincial and the central government levels to the international and global level (where it has so far been neglected) and for all organization, including private voluntary organizations and private firms (for which democratic participation has been much less discussed than for governments) and;

- Mobilize energies around several practical initiatives.

The report led to a more profound and positive view of culture and development. Culture was the fountain of progress and creativity and, in its full meaning, development encompasses cultural growth. Here the commission drew on ideas of human development, with which some of its members were already closely associated. ${ }^{32}$ As the very essence of

${ }^{32}$ Mahbub ul Haq was the founder of UNDP's Human Development Report and Keith Griffin and Lourdes Arizpe had been closely associated as consultants, especially in the first few years. All three were members of the Commission. 
human development is a process of broadening choices and strengthening human capabilities, cultural growth and cultural diversity add to the choices available and gives richness, depth and subtlety to human capabilities. As the commission put it, development is "a process that enhances the effective freedom of the people involved to pursue whatever they have reason to value". ${ }^{33}$

This implication of the report for human development has been well summarized by Commissioner Lourdes Arizpe, whose underlying argument is that development embraces not only access to goods and services but also the opportunity to choose a full, satisfying, valuable and valued way of living together. Looking at development as a process that enhances the effective freedom of people everywhere to create cultural expressions and to exchange them broadens the widely accepted notion of human development therefore, however important culture may be as an instrument of development (or as a constraint to development), it cannot be reduced to a subsidiary position as a mere promoter of (or an obstacle to) economic growth. "Culture is not a means to material progress; it is the end and aim of "development" seen as the flourishing of human existence in all its form as a whole". ${ }^{34}$ This reinforces the idea of "a process by which positive attitudes to peace, democracy, and tolerance are forged through education and knowledge about different cultures." ${ }^{35}$ Just as the founders of the United Nations dreamed of peace, so the World Commission on Culture and Development had a bold vision for a future built on the widest possible democratic mobilization.

The report was largely welcomed. According to many observers, its essence and goal was to defend the right of culture to develop and the right of humans to improve themselves in a creative, ethical and balanced environment that would respect cultural pluralism. Although some complained about the poor attention to transitional societies, their developmental difficulties and their prospects in the future, many appreciated the report's humanistic and universal understanding of culture and recommended national politicians to adopt this strategy.

The Preamble of the Intergovernmental Conference on Cultural Policies for Development, held at Stockholm (30 March-2 April 1998), cited the report of WCCD and in its declaration recalled the main principles. In particular, it recognized all goals expressed in the report: global ethics, pluralism, creativity and empowerment, the need to include gender issues, the importance of children, young people, the link between cultural heritage and development and between culture and environment. It finally recommended countries to adopt actions which were largely inspired by the contents of the WCCD report and its International Agenda.

Don Adams, representing the Institute for Cultural Democracy in Stockholm and as project director of Webster's World of Cultural Democracy, expressed appreciation of the "Our Creative Diversity" report, stating that it would represent for the government of the United States an important book to learn about key themes in cultural policy thinking and an ideal starting point for study.

\footnotetext{
${ }^{33}$ World Commission on Culture and Development, 1995, Our Creative Diversity - Report of the World Commission on Culture and Development (Paris: EGOPRIM), p. 22.

${ }^{34}$ Lourdes Arizpe, interview UNIHP

${ }^{35}$ World Commission on Culture and Development, 1995, Our Creative Diversity - Report of the World Commission on Culture and Development (Paris: EGOPRIM), p. 45.
} 
Context

By 1950 at least 45,000 large dams had been built in the world. On the plus side is regional development, job creation, fostering an industry base with export capability as well as creating income from export earning (either through direct sale of electricity or by selling cash crops or processed product from electricity-intensive industry). On the minus side, large dams have fragmented and transformed the world's rivers and global estimates suggest that 40-80 million people have been displaced by reservoirs. The decision to build a large dam has been increasingly contested, to the point where the future of large dam building in many countries is in question. The issue of dams and their benefits and impacts has become one of the battlegrounds in the sustainable development arena. The establishment of the commission and its report was presented as a contribution to a better understanding of the issues.

The World Bank and the World Conservation Union (IUCN) secured the initial core financial resources for the World Commission on Dams (WCD) to be created and to implement its work programme. WCD work began in May 1998 in Gland, Switzerland, convening 39 participants from governments, private sector, international financial institutions, civil society organizations and affected people.

The WCD, an independent body chaired by Prof. Kader Asmal (then South Africa's Minister of Water Affairs and Forestry) consisted of 12 commissioners who were chosen to reflect expertise, stakeholder perspectives and regional diversity: Africa (South Africa), Americas (US, Brazil), Asia (China, India, Philippines), Australia, EU (Austria, Germany, Sweden, Switzerland). The Secretariat was located in Cape Town, South Africa reinforcing its intention to serve developing countries in its approach to the task in hand. Achim Steiner was ex officio Secretary-General.

\section{Mandate}

The WCD mandate set: 1) reviewing the development effectiveness of large dams and assessing alternatives for water resources and energy development and 2) developing internationally acceptable criteria, guidelines and standards, where appropriate, for the planning, design, appraisal construction, operation, monitoring and decommissioning of dams. The WCD approach consisted in considering dams as a means to achieve sustainable improvement of human welfare, in the sense of economically viable, socially equitable and environmentally sustainable. If a large dam is the best way to achieve this goal, it deserves support. Where other options offer better solutions, they should be given preference.

\section{Outcome and impact}

The debate around dams challenged views of how societies develop and manage water resources in the broader context of development choices. In particular, it focused on the notion of costs versus reported benefits. To proponents, dams had generally performed well as an integral part of water and energy resource development strategies in over 140 nations and, with exceptions, have provided an indispensable range of water and energy services. Opponents contended that better, cheaper, more benign options for meeting water and energy needs exist and have been frequently ignored (from small-scale, 
decentralized water supply and electricity options to large-scale end-use efficiency and demand-side management options). Dams, it is argued, have often been selected over other options that may better meet water or energy goals at lower cost or that may offer development benefits that are more sustainable and more equitable.

The WCD analysed the two principal poles in the debate on large dams: one focuses on the gap between the promised benefits of a dam and the actual outcomes. The other looks at the challenges of water and energy development from a perspective of "nation-building" and resource allocation.

The main product of the WCD is its final report, Dams and Development: A New Framework for Decision Making, launched under the patronage of Nelson Mandela in November $2000 .^{36}$ It constituted:

- An independent review of the performance and impacts of large dams;

- An assessment of the alternatives to dams, the opportunities they provide and the obstacles they face and

- An analysis of planning, decision-making and compliance issues that underpin the selection, design, construction, operation and decommissioning of dams.

WCD supported the idea that along with all development choices, decisions on dams and their alternatives must respond to a wide range of needs, expectation, objectives and constraints. This new approach should be based on 1) a broad consensus on norms guiding development choices and the criteria defining the process for negotiation and decisionmaking; 2) five core values: equity, efficiency, participatory decision-making, sustainability and accountability and 3) a rights-and-risks perspective, as an effective framework to determine who has a legitimate place at the negotiation table and what issues need to be on the agenda.

Clarifying the rights-and-risks context for a proposed project implied the identification of 1) those legitimate claims and entitlements that might be affected by the proposed project - or its alternatives and 2) those entitled to a formal role in the consultative process, and eventually in negotiating project-specific agreements.

In this way, not only developers or corporate investors would be involved in assessing and planning project, but also stakeholder groups, those directly affected by a project, and the environment as a public good.

WCD listed seven strategic priorities for an equitable and sustainable development of water and energy resources:

- Gaining public acceptance;

- Comprehensive options assessment;

- $\quad$ Addressing existing dams;

- Sustaining rivers and livelihoods;

- Recognizing entitlements and sharing benefits;

- $\quad$ Ensuring compliance;

${ }^{36}$ The World Commission on Dams, 2000, Dams and Development: A New Framework for Decision Making (London: Earthscan). 
- Sharing rivers for peace, development and security.

WCD recommended national governments to:

- Require a review of existing procedures and regulations concerning large dam projects;

- Adopt the practice of time-bound licences for all dams, whether public or privately owned;

- Establish an independent, multi-stakeholder committee to address the unresolved legacy of past dams.

Civil society groups to:

- Monitor compliance with agreements and assist any aggrieved party to seek resolution of outstanding disagreements or to seek recourse;

- Actively assist in identifying the relevant stakeholders for dam projects, using the rights-and-risks approach.

Affected people to:

- Identify unresolved social and environmental impacts and convince the relevant authorities to take effective steps to address them

- Develop support networks and partnerships to strengthen the technical and legal capacity for needs and options assessment processes

Professional associations to:

- Develop processes for certifying compliance with WCD guidelines;

- Extend national and international databases, such as the ICOLD World Register of Dams, to include social and environmental parameters.

The private sector to:

- Develop and adopt voluntary codes of conduct, management systems and certification procedures for best ensuring and demonstrating compliance with the commission's guidelines including, for example, through the ISO 14001management system standard;

- Abide by the provisions of the anti-bribery convention of the Organisation for Economic Co-operation and Development;

- Adopt integrity pacts for all contracts and procurement.

Bilateral aid agencies and multilateral development banks to:

- Ensure that any dam options for which financing is approved emerge from an agreed process of ranking of alternatives and respect the WCD guidelines;

- Accelerate the shift from project- to sector-based finance, especially through increasing financial and technical support for effective, transparent, and participatory needs and options assessment, and the financing of non-structural alternatives; 
- Review the portfolio of projects to identify any past ones that may have underperformed or present unresolved issues.

The WCD report has been widely acknowledged; organizations such as the World Bank and the World Health Organization endorsed its conclusions and supported the recommendations and strategic priorities. The Asian Development Bank declared that it would re-examine its own procedures, including environmental and social development policies, and encouraged its member countries to do the same. The African Development Bank planned to incorporate the criteria and guidelines during the development of the Bank's technical guidelines to support its own policy on Integrated Water Resources Management. It also committed to revise its Environmental Policy to give a stronger emphasis to the social issues typically relevant for large infrastructure projects.

Strong support for the report also came from NGOs like the Commission to Action, whose call for action has been endorsed by 109 NGOs from 39 countries. In particular, the Coalition of Conservation groups sent an open letter to the President of the United States and Congress encouraging them to follow WCD recommendations.

Appreciation has also been expressed by Jamey Bay Cree Nation and Pimicikamak Cree Nation, indigenous people in the Quebec and the Manitoba regions of boreal, subartic Canada who have been adversely affected by hydro-electric projects involving river diversions and river basin re-engineering since the 1970s.

A civil society organization, the International Commission on Large Dams (ICOLD) expressed reservations on the report, complaining of poor efforts to bring the debate on the pros and cons of dams to a higher level and the not always rigorous examination of dams and their benefits. By affirming that poverty is the biggest enemy of environment, the ICOLD expressed concerns that the Report might be viewed as anti-developmental.

\subsection{International Commission on Intervention and State Sovereignty (September 2000-September 2001)}

\section{Context}

The establishment of the Commission on Intervention and State Sovereignty is related to the full-blooded debate within and outside the UN system on the implication of the Kosovo crisis for international politics. Kofi Annan played a key role - in particular in his opening address to the UN General Assembly on 20 September 1999 - in designing new principles of sovereignty and humanitarian intervention. External military intervention for human protection purposes has been controversial both when it happened - as in Somalia, Bosnia and Kosovo - and when it failed to happen, as in Rwanda. Mr. Annan said that the challenges of globalization and international cooperation required redefinition of the concept of sovereignty of States since the state must be perceived as the servant of the people and not vice versa.

At the United Nations (UN) Millennium Assembly in September 2000, Canadian Prime Minister Jean Chrétien announced that an independent International Commission on Intervention and State Sovereignty (ICSS) would be established as a response to the UN Secretary-General's challenge to the international community to try to find, once and for all, a new consensus on how to approach intervention and state sovereignty in case of massive violations of human rights and humanitarian law and to "forge unity" around the basic questions of principle and process involved. 


\section{Mandate}

Launched on September 14, the mandate of the ICISS was to 1) promote a comprehensive debate on the relationship between intervention and state sovereignty from political ethical, legal and operational perspectives; 2) consult with the widest possible range of opinion around the world; 3 ) foster global political consensus on how to move toward action within the international system, particularly through the UN and 4) compile a report that would help all actors and stakeholders to find some new common ground.

The ICISS was an independent body which intended to support the UN and complement efforts already undertaken on these issues in other contexts. It was proposed that the ICISS complete its work within a year, enabling the Canadian Government to take the opportunity of the $56^{\text {th }}$ session of the UN General Assembly to inform the international community of ICSS's findings and recommendations for action.

The Canadian Government appointed Gareth Evans and Mohammed Sahnoun as Co-Chairs of ICISS. In consultation with them ten commissioners were appointed.

\section{Outcome and impact}

Discussion focused on state sovereignty, intervention and prevention as three essential elements of the contemporary debate on the use of coercive means to secure humanitarian objectives. In particular:

- State sovereignty denotes the competence, independence and legal equality of States. It is used to encompass all matters in which each state is permitted by international law to decide and act without intrusions from other sovereign states. It is presented as a key constitutional safeguard of international order, although there are important and widely accepted limits to state sovereignty and to domestic jurisdiction in international law;

- Intervention means various forms of non-consensual action that are often thought to directly challenge the principle of state sovereignty. The essence of the debate stems from two basic questions: Does a right of humanitarian intervention exists? And if so, whose right is it?

- $\quad$ Prevention is broadly understood to involve strategies addressing both proximate and underlying causes. "There is near-universal agreement that prevention is preferable to cure" notes Kofi Annan, "and that strategies of prevention must address the root causes of conflicts, not simply their violent symptoms." Nevertheless, conflict prevention has remained underdeveloped, undervalued, ephemeral and largely elusive.

The main outcome of the ICISS work was a report whose central theme is reflected in the title, The Responsibility to Protect. A supplementary volume to the report, whose primary authors are Thomas G. Weiss and Don Hubert, was also published. ${ }^{37}$

Faced with the seemly irreconcilable notions of intervention and state sovereignty the report introduced the concept of responsibility. This starting point effectively turned the whole debate on its head to recharacterize it not as an argument about the right to

${ }^{37}$ ICSS, 2001, The Responsibility to Protect- The Report (Ottawa: IDRC) and ICSS, 2001, The Responsibility to Protect: Research, Bibliography, Background - Supplementary Volume (Ottawa: IDRC). Both publications are available on CD-rom and on the web site www.iciss.gc.ca. 
intervene' but about the 'responsibility to protect' — a responsibility owed by all sovereign States to their own citizens in the first instance, but one that must be picked up by the international community of States, if that first-tier responsibility is abdicated, or incapable of exercise.

The commission's wording of the report avoided the notions of right to intervene or human intervention, to forestall sterile conflicts among the commissioners and the possible rejection of the recommendations of the report by a large number of governments. A consensus was built on the notion of responsibility to protect which was less confrontational with the principles of sovereignty (one of the overarching principles of the United Nations).

The foundation of the responsibility to protect, as a guiding principle for the international community of States, lies in the obligation inherent in the concept of sovereignty as well as in the responsibility of the Security Council (article 24 of the UN charter), specific international legal obligations and developing practice of States, regional organizations and the Security Council itself.

According to the report, the responsibility to protect implies three specific responsibilities:

- The responsibility to prevent: preventative options addressing both the root causes and direct causes of internal conflict should always be exhausted before intervention is contemplated;

- The responsibility to react: to respond to a situation of compelling human need with appropriate measures. When preventive measures fail to resolve or contain the situation and when a State is unable or unwilling to redress the situation, then intervention measures by other members of the broader community or State may be required. These coercive measures may include political, economic or judicial measures, but military action only in extreme cases. The exercising of the responsibility to both prevent and react should always involve the consideration of less intrusive and coercive measures before more coercive and intrusive ones are applied;

- The responsibility to rebuild: responsibility to protect implies the responsibility not just to prevent and react, but also to follow through and rebuild, particularly after a military intervention. There should be a genuine commitment to fostering a durable peace and promoting good governance and sustainable development. Conditions of public safety and order have to be reconstituted by international agents acting in partnership with local authorities, with the goal of progressively transferring to them the authority and responsibility to rebuild.

The concept of responsibility to protect led to the very powerful idea of military intervention for human protection purposes which is an exceptional and extraordinary measure that implies an evaluation of the issues from the point of view of those seeking or needing support, rather than those who may be considering intervention. It is justifiable only when every non-military option for intervention or peaceful resolution of the crisis has been explored, with reasonable grounds for believing lesser measures would not have succeeded "last resort". To be warranted, there must be a large-scale loss of life, actual or apprehended, or a large-scale ethnic cleansing, actual or apprehended "just cause". Its primary purpose must be to halt or avert human suffering "right intention". The scale, duration and intensity of a planned military intervention should be the minimum necessary to secure the defined human protection objective "proportional means" and there must be a reasonable chance of success in halting or averting the suffering, with the consequences of action not likely to be worse than the consequences of inaction "reasonable prospects". 
The ICISS defined the UN Security Council as the appropriate body to authorize military intervention for human protection purposes. Its authorization should in all cases be sought prior to any military intervention action being carried out and precautionary criteria being satisfied. The ICISS did not want to enter in to the debate on whether the Security Council should be reformed or not, but it supported the idea that a "code of conduct" be agreed by the Permanent Five members of the Security Council. In matters where its vital national interests were not claimed to be involved, a permanent member would not use its veto to obstruct the passage of resolutions authorizing military intervention for human protection purposes for which there is otherwise majority support.

The ICISS recommended to the General Assembly:

That the General Assembly adopts a draft declaratory resolution embodying the basic principles of the responsibility to protect, and containing four basic elements:

- An affirmation of the idea of sovereignty as responsibility;

- An assertion of the threefold responsibility of the international community of States — to prevent, to react and to rebuild - when faced with human protection claims in States that are either unable or unwilling to act on their responsibility to protect;

- A definition of the threshold (large scale loss of life or ethnic cleansing, actual or apprehended) which human protection claims must meet if they are to justify military intervention; and

- An articulation of the precautionary principles (right intention, last resort, proportional means and reasonable prospects) that must be observed when military force is used for human protection purposes.

The ICISS also recommended to the Security Council:

- That the members of the Security Council should consider and seek to reach agreement on a set of guidelines, embracing the "Principles for Military Intervention" summarized in the Synopsis, to govern their responses to claims for military intervention for human protection purposes.

- That the Permanent Five members of the Security Council should consider and seek to reach agreement not to apply their veto power, in matters where their vital state interests are not involved, to obstruct the passage of resolutions authorizing military intervention for human protection purposes for which there is otherwise majority support.

Finally, the ICISS recommended:

- That the Secretary-General give consideration, and consult as appropriate with the President of the Security Council and the President of the General Assembly, as to how the substance and action recommendations of this report can best be advanced in those two bodies, and by his own further action.

It is important to note that the ICISS report was largely completed before the appalling attacks of 11 September 2001 on New York and Washington DC, and was not conceived as addressing the kind of challenge posed by such attacks. Nevertheless, the ICISS recognized that there are aspects of the report, which do have some relevance to the issues with which the international community has been grappling in the aftermath of those attacks. In particular, the precautionary principles outlined in the report seem to be relevant to military operations, both multilateral and unilateral, against the scourge of 
terrorism. As stated in the Foreword, "We have no difficulty in principle with focused military action being taken against international terrorists and those who harbour them. But military power should always be exercised in a principled way, and the principles of right intention, last resort, proportional means and reasonable prospects outlined in our report are, on the face of it, all applicable to such action."

In his message to the International Peace Academy seminar in New York City on The Responsibility to Protect Kofi Annan expressed profound gratitude to the Government of Canada, and to the Co-Chairs of the commission, Gareth Evans and Mohammed Sahnoun, as well as their fellow commissioners, for their remarkable accomplishment. In particular, he recognized that a central accomplishment of the report is its title - a restatement of the core issue at the heart of the debate on intervention - and the subsequent constructive shift away from debates about a "right to intervene" towards the assertion of a "responsibility to protect" (although the events of September 11 risk shifting the debate and the action - away from military intervention on behalf of others to intervention in self-defence).

The UN Secretary-General noted how the responsibility to prevent and the responsibility to rebuild are particularly crucial questions in Afghanistan, where international community is desperately trying to ensure that the international community stays engaged. Prevention, Mr. Annan recalled, in the case of Afghanistan today, means ensuring that security is provided throughout the country, and not just in Kabul, otherwise there is the risk of returning to violence and conflict.

\subsection{The Commission on Macroeconomics and Health (2000-2001)}

\section{Context}

The benefits of globalization are potentially enormous, but globalization is under trial because these benefits are not yet reaching hundreds of millions of the world's poor, and partly because globalization introduces new kinds of international challenges: turmoil in one part of the world can spread rapidly to others, through terrorism, armed conflict, environmental degradation, or disease (such as the dramatic spread of AIDS around the globe in a single generation).

Although the 20th century has brought about dramatic improvements in health, over one billion human beings have been left behind in the health revolution. The burden of disease and disability on the poor remains unbearable in many parts of the world, both in terms of suffering and the economic strains it imposes. For example, the tragedy of the HIV epidemic continues to take a heavy toll and increases young adult mortality in sub-Saharan Africa.

Improving the health and longevity of the poor is an end in itself, a fundamental goal of economic development. But it is also a means to achieving the other development goals relating to poverty reduction. The linkages of health to poverty reduction and to long-term economic growth are powerful. The burden of disease in some low-income regions of the world is a stark barrier to economic growth and therefore must be addressed frontally and centrally in any comprehensive developmental strategy. The Millennium Development Goals (MDGs), adopted at the Millennium Summit of the United Nations in September 2000 , called for a marked reduction in poverty and improvements in the health status of the poor. 
The Commission on Macroeconomics and Health $(\mathrm{CMH})$ was established by the World Health Organization Director-General Gro Harlem Brundtland in January 2000 to assess the place of health in global economic development. Thirteen years after the Brundtland Commission established the indisputable link between environment and development, the $\mathrm{CMH}$ was asked to clarify the link between health and poverty reduction. The commission was composed of 18 members and one Chair, Jeffrey Sachs.

\section{Mandate}

The mandate was to assess critically and generate further evidence on:

- The nature and magnitude of the economic outcomes (income and productivity growth, poverty reduction and social protection) of investing in health;

- The economics of incentives for research and development of drugs and vaccines that address diseases primarily affecting the poor;

- Effective and equitable mobilization of resources required to deal with major disease problems of the poor and to develop and sustain health systems more generally;

- Health and international economic relations (such as trade-related issues);

- Development assistance and health (including consideration of efficiency in use of assistance oriented to improving health, consequences of adjustment and stabilization policies for health and the health sector, and debt relief) and

- Costs and efficiency in addressing major diseases of the poor.

To that aim six working groups were formed:

1) Health, Economic Growth and Poverty Reduction: it addressed the impact of health investments on poverty reduction and economic growth;

2) Global Public Goods for Health: it studied multicultural policies, programmes and initiatives having a positive impact on health that extends beyond the borders of any single country. It commissioned over 20 research papers in three major categories research, R\&D for neglected products and building research capacity in the developing countries; global aspects of communicable disease control and prevention; information and dissemination of best practice;

3) Mobilization of Domestic Resources for Health: it assessed the economic consequences of alternative approaches to resource mobilization for health systems and interventions form domestic resources. This work was carried out in collaboration with the International Monetary Fund and other institutions. It focused on how health system can best be financed at country level, including by reallocation of public sector budgets and by expanding the role of governmental sector;

4) Health and International Economy: it examined trade in health services, health commodities and health insurance, patents for medicines and Trade-Related Intellectual Property Rights (TRIPS), international movements of risk factors, international migration for health workers, health conditions and health finance policies as rationale for protection and other ways that trade may be impacting on the health sector;

5) Improving Health Outcomes of the Poor: it examined the technical options, constraints and costs for mounting a major global effort to improve the health status of the poor dramatically by 2015 . It undertook analyses of avoidable mortality, identified available interventions to address the key causes, reviewed evidence on 
how to relax constraints, and estimated the costs of scaling up coverage of key interventions along with the costs of the required system strengthening;

6) Development Assistance and Health: it reviewed health implications of development assistance policies including modalities relating to debt relief. It focused on the policies and approaches of international developmental agencies.

\section{Outcome and impact}

The commission focused on the low-income countries and on the poor in middle-income countries. The low-income countries, with 2.5 billion people and especially the countries of Sub-Saharan Africa, with 650 million people, have far lower life expectancies and far higher age-adjustment mortality rates that the rest of the world. The same is true for the poor in middle-income countries, such as China.

The commission also focused on communicable diseases and maternal and perinatal health, although non-communicable diseases (NCDs) are also of great importance for all developing countries. For many middle-income countries the mortality from communicable diseases has already been significantly reduced so that the NCDs tend to be the highest priority.

Main causes of avoidable deaths in the low-income countries are HIV/AIDS, malaria, tuberculosis (TB), childhood infectious diseases, maternal and perinatal conditions, micronutrient deficiencies, and tobacco-related illness. They remain the main contributors to the overall global burden of disease and to mortality among children, against a backdrop of chronic malnutrition. But at the same time, and in the same countries of the developing world, the mounting burden of heart diseases, cancer, diabetes, accidents and mental health conditions is set against a backdrop of ageing and new risk factors of which tobacco use is the most prominent.

If these conditions were controlled in conjunction with enhanced programmes of family planning, impoverished families could not only enjoy lives that are longer, healthier and more productive, but they would also choose to have fewer children, secure in the knowledge that their children would survive and could thereby invest more in the education and health of each child. The improvement in health would translate into higher incomes, higher economic growth and reduced population growth.

The commission produced a final report, Macroeconomics and Health: Investing in Health for Economic Development which outlines the strategy to reduce poverty and improve health. The resources - human, scientific and financial - exist to succeed, but must be mobilized. Indeed, the war against disease requires financial resources, but also a strategy, with operational lines of responsibility and the capacity to learn along the way. For lowincome countries, there is still a gap between financial means and financial needs which can be filled only by donors (if there is to be any hope of success in meeting the MDGs). For most middle-income countries, average health spending per person is already adequate to ensure universal coverage for essential intervention, but such coverage does not reach many of the poor.

The commission therefore devoted substantial effort to analysing the organizational practicalities of a massive, donor-supported scaling up of health interventions in the lowincome countries. The world's low and middle-income countries, in partnership with highincome countries, should scale up the access of the world's poor to essential health services including a focus on specific interventions. 
The low and middle-income countries would commit additional domestic financial resources; political leadership, transparency and systems for community involvement and accountability, to ensure that adequately financed health systems can operate effectively and are dedicated to the key health problems. The high-income countries would simultaneously commit vastly increased financial assistance, in the form of grants, especially to the countries that need help most urgently, which are concentrated in subSaharan Africa. The commitment of massive additional financial resources for health, domestic and international, may be a necessary condition for scaling up health interventions, but the commission recognizes that such a commitment will not be sufficient. Indeed, political and administrative commitment from both donors and countries are important. Building health systems that are responsive to client needs, particularly for poor and hard-to-reach populations, requires politically difficult and administratively demanding choices.

Since scaling up will require a significant increase in international financing, an effective partnership of donors and recipient countries, based on mutual trust and performance is essential. In this context, the mechanism of donor financing must follow the Poverty Reduction Strategy Paper (PRSP) Framework, which includes: 1) deeper debt cancellation; 2) country leadership in the preparation of the national strategy; 3 ) explicit incorporation of civil society at each step of the process; 4) a comprehensive approach to poverty reduction and 5) more donor coordination in support of country goals. Within the context of PRSP, the commission recommended that each developing country establish a temporary National Commission on Macroeconomics and Health $(\mathrm{NCMH})$ or its equivalent, chaired jointly by the Minister of Health and Finance, and incorporating a key representative of civil society to organise and lead the task of scaling up. Each NCMH would assess national health priorities, establish a multi-year strategy to extend coverage of essential health services, take account of synergies with other key health producing sectors, and ensure consistency with a sound macroeconomic policy framework.

The partnership would then proceed step by step. Each country should define an overall program of "essential interventions" to be guaranteed universal coverage through public and donor financing. The commission suggested four criteria in choosing these essential interventions: 1) they should be technically efficacious and deliverable; 2) the targeted diseases should impose a heavy burden on society, taking into account individual illness as well as social spillovers (such as epidemics and adverse economic effects); 3) social benefits should exceed costs of the interventions (with benefits including life-years saved and spillovers such as fewer orphans or faster economic growth) and 4) the needs of the poor should be stressed.

Actions in the low-income countries creating the conditions for donor financing such as: 1) reinforcing the political leadership in order to create conditions for honesty, trust and respect of donor-recipient interactions; 2) commitment in the private and public sectors, as well as in civil society, to make efforts in those settings in which health conditions are most troubling and where public sectors are weak; 3) building local capacity and involving the civil society and NGOs in order to provide an antidote to the despair and hatred that poverty can breed; 4) improving health-sector management; 5) reviewing the current balance among health-sector programs and 6) raise domestic resources for health within their means.

A sound global strategy for health should be based on the close-to-client (CTC) system, which would involve a mix of state and non-state health service providers, with financing guaranteed by the State, through direct own and service units or through contract for services with for-profit and non-profit providers. National leadership, coupled with capacity and accountability at the local level, is therefore vital. This will require new 
political commitments, increased organizational and supervisory capacity at both local and higher levels, and greater transparency in public services and budgeting - all backed by more funding. These, in turn, must be built on a foundation of strong community-level oversight and action, in order to be responsive to the poor, in order to build accountability of local services and in order to help ensure that families take full advantage of the services provided.

It is also important to invest in new knowledge. The commission called for a significant scaling up of financing for global R\&D on the heavy disease burdens of the poor, for research into reproductive health, and improved management of life-threatening obstetric conditions. There is the need for increasing investments in other areas of knowledge as well, such as enhancing system of advising, training and diffusing new knowledge and best practices.

Finally, the commission stressed the need for complementary additional investments in areas with an important impact on poverty alleviation, including effects on health. These include education, water and sanitation and agricultural improvement. Education is a key determinant of health status - as health is of education status.

\subsection{The Commission on Human Security (January 2001-December 2002)}

\section{Context}

Collective efforts to reduce human suffering and insecurity where it is most acute and prevalent are a growing concern in the international community. Expressed by the term "human security" this debate has become a central focus of policy imperative for many nations. Japan, in particular, expressed its commitment to sustain the debate on human security. In his policy speech in December 1998, the late Prime Minister of Japan, Keizo Obuchi, defined human security as the key concept in the comprehensive approach to the menaces that threaten the survival, daily life, and dignity of human beings and in strengthening the efforts to confront these threats. Prime Minister Yoshiro Mori, in his statement at the UN Millennium Summit, announced his Government's plan to make an additional substantial contribution to the Trust Fund for Human Security that was established at the UN in March 1999 to promote specific efforts for human security. Such initiatives for promoting human security have been broadly supported by Asia-Pacific, African, European and North American countries.

The Commission on Human Security (CHS) was set up in response to the UN SecretaryGeneral's call for the Millennium Summit in September 2000 to achieve the twin goals of "freedom from fear" and "freedom from want".

The CHS was conceived by several leaders around the world in order to seize this opportunity of enhanced awareness about human security and, as stated in the UN Millennium Declaration, to promote broad and sustained efforts to create a shared future, based upon our common humanity in the era of globalization.

The CHS was an independent body, whose Co-Chairs, Mrs Sadako Ogata, former UN High Commissioner for Refugees and Prof. Amartya Sen, Nobel Laureate and Master of Trinity College, Cambridge, guided the work of the commission and its secretariat. They oversaw specific projects with the participation of interested commissioners. 


\section{Mandate}

Its mandate has been defined as: 1) promoting public understanding, engagement and support of human security and its underlying imperatives; 2) developing the concept of human security as an operational tool for policy formulation and implementation; and 3) proposing a concrete programme of action to address critical and pervasive threats to human security.

The objective of human security is to safeguard the vital core of all human lives from critical pervasive threats, in a way that is consistent with long-term human fulfilment. Institutions that undertake to protect human security will not be able to promote every aspect of human-well being, but at the least they will try to protect this vital core of fundamental human rights and freedoms pertaining to survival, livelihood and basic dignity.

In this sense human security is deliberately protective. Safeguarding human lives implicated not only those institutions that intend to promote human security overtly, but also institutions that unintentionally undermine it. Strategies that are associated with providing human security identify the threats and then seek to prevent threats from materializing; mitigate harmful effects and help victims cope (a response approach so that victims or the chronic poor survive with dignity and maintain their livelihoods). A second approach to human security protection is respect, which means that whatever their primary objective may be, all actors, whether institutional, corporate or individual, must ascertain that their actions may unintentionally threaten human security.

Human security is people-centred. The human security approach parallels the movement in economic development and international law to shift the emphasis from instrumental objectives (such as growth or state right) to human development and human rights. In doing so, the human being becomes the "end" of development, not only the "means" to increased economic productivity or legal coherence and, in turn these various activities become "people-centred".

Human security relates to the identification and assessment of both critical (cutting into core activities and functions) and pervasive (large-scale, recurrent dangers) threats. At the same time, human security is not sufficient for human fulfilment and therefore it must be inscribed in a long-term human fulfilment strategy, which should be consistent with ongoing human development by supporting participation, freedom, institutional appropriateness and diversity.

Following the announcement of its establishment in January 2001, the first meeting took place at the Greentree Estate from 8 to 10 June 2001, which set the above guiding principles of its work. The following additional issues were brought forward as requiring special attention:

- Ensuring human security is not limited to meeting material needs;

- Due attention should be paid to equity, human rights and the process of justice;

- Gender issues should receive close attention;

- The impact of globalization processes upon human security needs to be assessed;

Concern was expressed about equating or using human security as a pretext for humanitarian intervention. Considerable work is already being conducted by other entities in this field (e.g. Commission on Humanitarian Intervention and State Sovereignty). 
Before the completion of the final report four official meeting took place, respectively in New York on June 2001, Tokyo on December 2001, Stockholm on June 2002 and in Thailand on January 2003. Moreover a series of outreach activities were organized such as the "Symposium on Economic Insecurity in Africa" in Cotonou, Benin on May 2002, the meeting on "Human Security, Human Rights, and Human Development" at Harvard Kennedy School on February 2002, the meeting on "Transition in Central Asia and Human Security" in Ashgabat, Turkmenistan on April 2002, the Workshop on "Education, Equity and Security" in Kolkata, India on January 2002, the "Workshop on Relationship Between Human Rights and Human Security" in San Jose, Costa Rica on December 2001 or the "Workshop: Measurement of Human Security" at Harvard Kennedy School on November 2001.The commission reviewed two major events that had taken place at the initiative of various commissioners prior to the Tokyo meeting:

\section{Outcome and impact}

Two research projects were launched to support the Commission's work: one on conflict and the other on development. The Conflict Project focused on a) the security of civilians (refugees and internally displaced persons) during conflict, b) the coexistence of communities following conflict, and c) the 'gap' between emergency relief and development. Four additional areas of interest were: a) causes of conflict, focusing on discrimination and citizenship; b) gender-based violence; c) the criminalisation of violence; and d) funding for human security. The Conflict Project aimed at synthesising existing research as well as undertaking new research. As far as possible, the project seek to promote operational initiatives aimed at enhancing the security of people in selected areas.

The Development Project was located in Harvard, but worked largely in the South. The aim was to do research and consultation on the value-added of the Human Security lens in various sectors: health, education, inequality, gender, and 'new insecurities'. Research papers have been commissioned on these to examine the inter relationships and substantive policy aspects with human security. The Development Project also looked at the data and concepts of human security, and map the institutions associated with human security (in conjunction with the Conflict Project).

The outcome of both research projects have contributed to the drafting process of the Report.

The Commission has presented the Final Report to UN Secretary-General Kofi Annan on May 1, 2003. The report's call for human security is a response to the challenges in today's world. Policies and institutions must respond to these insecurities in stronger and more integrated ways. To attain the goal of human security, the Commission proposes a framework based upon the protection and empowerment of people where the state continues to have the primary responsibility for security. But as security challenges become more complex and various, new actors attempt to play a role and the focus must broaden from the state to the security of people. Thus the Report calls for a shift in paradigm based on human security.

Human security connects different types of freedoms - freedom from want, freedom from fear and freedom to take action on one's own behalf. To do this, it offers two general strategies: protection and empowerment. Protection shields people from dangers. It requires concerted effort to develop norms, processes and institutions that systematically address insecurities. Empowerment enables people to develop their potential and become full participants in decision-making. Protection and empowerment are mutually reinforcing, and both are required in most situations. The report calls for the 
implementation of a protection-empowerment framework which is a key feature of good governance and the States have the primarily responsibility to implement an appropriate protective set of institutions.

The concept of human security complements two other key human centered concepts, namely human rights and human development which are now at the heart of the new development paradigm. Indeed, human security by emphasising the need for a protectionempowerment framework gives better means to realize human rights. Human security also adds to the human dimension of development thinking by emphasizing the important policy dimension of assuring security in sudden and unforeseen downturn that may give rise to political and social instability leading sometimes to violent conflicts.

The Commission has examined six broad priorities from a human security perspective and formulated several policy recommendations:

1) Protecting people in violent conflict. Civilians are the main casualties in conflicts. Both norms and mechanisms to protect civilians should be strengthened. This requires comprehensive and integrated strategies, linking political, military, humanitarian and development aspects. The Commission proposes placing human security formally on the agenda of security organizations at all levels.

2) Protecting and empowering people on the move. The feasibility of an international migration framework should be explored, through establishing the basis of high-level and broad-based discussions and dialogues on the need to strike a careful balance between the security and development needs of countries, and the human security of people on the move. Equally important is to ensure the protection of refugees and internally displaced persons, and identify ways to end their plight.

3) Protecting and empowering people in post-conflict situations. The responsibility to protect people in conflict should be complemented by a responsibility to rebuild. A new framework and a funding strategy are necessary to rebuild conflict-torn states - one that focuses on the protection and empowerment of people.

4) Economic insecurity - the power to choose among opportunities. Efficient and equitable trade arrangements, economic growth reaching the extreme poor and a fair distribution of benefits are essential. An equitable distribution of resources is key to livelihood security and can enhance people's own capacity and ingenuity.

5) Health for human security. It is essential to mobilize social action and invest in supportive social arrangements, including the access to information, to remove the root causes of ill-health, to provide early warning systems and to mitigate health impacts once a crisis occurs. An equitable intellectual property rights regime needs to be developed to balance incentives for research and development with ensuring people's access to affordable life-saving drugs.

6) Knowledge, skills and values - for human security: Basic education and public information that provide knowledge, life skills and respect for diversity are particularly important for human security. The Commission urges the international community to actively help the achievement of universal primary education, with a particular emphasis on girls' education.

Based on the foregoing the Commission has arrived at policy conclusions in the following areas.

1) Protecting people in violent conflict

2) Protecting people from the proliferation of arms 
3) Supporting the security of people on the move

4) Establishing human security transition funds for post-conflict situations

5) Encouraging fair trade and markets to benefit the extreme poor

6) Working to provide minimum living standards everywhere

7) According higher priority to ensuring universal access to basic health care

8) Developing an efficient and equitable global system for patent rights

9) Empowering all people with universal basic education

10) Clarifying the need for a global human identity while respecting the freedom of individuals to have diverse identities and affiliations.

The Commission calls for the establishment of a network of public, private, and civil society actors who could help in the clarification and development of norms, embark on integrated activities, and monitor progress and performance. From this perspective, human security could serve as a catalytic concept that links many existing initiatives but an effective and adequate resource mobilization is also required. And finally, the Commission recommends the establishment of an Advisory Board on Human Security to provide orientation to the UN Trust Fund and follow-up on the Commission's recommendations. 


\section{Part 3: Description of International Commissions' Work Process and Funding}

From an organizational perspective, there are wide variations among the commissions on the number of commissioners, budgets, Secretariat staff, work processes and time-spans. Their success will ultimately depend on the way the report is presented (must not be intended as a technical document); the commitment of commission members to promoting a large public debate; the authority and personality of the commissioners and, on the senior staff members of the secretariat, the advisory panels of experts and other experts preparing background papers, who provide an invaluable resource base for the work of the commissions and the drafting of their final reports. In the work process, the establishment of some thematic working groups and panels of relevant experts has been widely used by the commissions to facilitate their tasks.

\subsection{Independent Commission on International Development Issues}

Duration: 2 year mandate (December 1977 - December 1979)

Members: Chair - Willy Brandt, 20 members $=21$ in total.

The members were: Abdlatif Al-Hamad (Kuwait), Rodrigo Botero Montoya (Bogota), Antoine Dakouré (Burkina Faso), Eduardo Frei Montalva (Chile), Katharine Graham (US), Edward Heath (UK), Amir Jamal (Tanzania), Lakshimi Kant Jha (India), Khatijah Ahmad (Malaysia), Adam Malik (Indonesia), Haruki Mori (Japan), Joe Morris (Canada), Olof Palme (Sweden), Peter Peterson (US), Edgard Pisani (France), Shridath Ramphal (Guyana), Layachi Yaker (Algeria). Ex officio members: Jan Pronk (Netherlands), Goran Ohlin (Sweden), Dragoslav Avramovic (Yugoslavia).

\section{Work process:}

The consultations took over two years. The commission held ten meetings between December 1977 and December 1979 in different parts of the world. A series of background papers on a number of North-South issues were prepared by 16 experts. A selection of background papers were published separately. The Secretariat also appealed to hundreds of research institutes and many international organizations all over the world to submit reports of recent work or work in progress. The Brandt Commission presented its report to the Secretary-General of the United Nations on February 12, 1980. The report was published as North-South: A Programme for Survival and it had been translated into 21 languages.

The success of the Brandt Report has largely resulted from the commitment of the members to promoting a large public debate on their analysis and recommendation. For example, in May 1980, two months after the publication of the report, the Dutch Government organized an important symposium in which the majority of the members of the Brandt Commission participated. So too did more than 2,000 people from civil society organizations, trade unions and leaders of political parties. The multiplication of this type of event played a great role in the visibility of the report and its intellectual impact on the main debates. The European Commission followed the same strategy with its "green book" on the future of ACP-EU cooperation, for example, organizing a vast series of workshops and conferences at national and regional levels, convening public authorities and civil society, employers and workers' representatives to discuss the proposal of the report. 
The commission ceased to exist as a formal body and its secretariat was dissolved. Although there was no formal follow-up, a small office was established in The Hague to deal with requests, comments etc.

Support: Secretariat in Geneva of 15 professional staff, 3 interpreters, 3 research assistants, 19 administrative staff.

Funding: The Dutch Government financed half of the Commission's original budget, and supported the follow-up office. Other contributions came from the Governments of Denmark, Norway, Sweden, and the UK. The OPEC Fund supported follow-up work through untied contributions.

\subsection{Independent Commission on International} Humanitarian Issues

Duration: Six years to complete its work, 1983-1988.

Members: Co-chairs - Sadruddin Aga Khan and Hassan bin Talal

27 members $=29$ in total. Members appointed on basis of equitable geographical representation: Susanna Agnelli (Italy), Talal bin Abdul Aziz Al Saud (Saudi Arabia), Paulo Evaristo Arns (Brazil), Mohammed Bedjaoui (Algeria), Henrik Beer (Sweden), Igor P. Blishchenko (URSS), Luis Echeverria Alvarez (Mexico), Pierre Graber (Switzerland), Ivan L. Head (Canada), M. Hidayatullah (India), Aziza Hussein (Egypt), Manfred Lachs (Poland), Robert S. McNamara (USA), Lazar Mojsov (Yugoslavia), Mohammed Mzali (Tunisa), Sadako Ogata (Japan), David Owen (United Kingdom), Willibald P. Pahr (Austria), Shridath S. Ramphal (Guyana), Ru Xin (China), Salim A Salim (Tanzania), Léopold Sédar Senghor (Senegal), Soedjatmoko (Indonesia), Desmond Tutu (South Africa), Simone Weil (France), E.Gough Whitlam (Australia).

\section{Work process:}

The plenary meetings of ICIHI after the launching of the commission were:

- New York, November 1983: discussion of the preliminary papers submitted to it on the three areas of study;

- Hammamet, Tunisia, May 1984: special attention to the situation of Africa at that time and public statement on series of recommendations relating to short and longterm measures that could be taken to address the problem of famine;

- The Hague, the Netherlands, December 1984: review of the work on famine, desertification and deforestation and early-warning systems and special session devoted to the problems of youth;

- UN University, Tokyo, June 1985: consideration to the various vulnerable groups and special attention to refugees; displaced persons and indigenous peoples; announcement of publication of the book on famine;

- Vienna, Austria, December 1985: notification of the sectoral reports on desertification and deforestation, which followed the book on famine and examination of the working group reports on street children, disappearances and refugees; 
- Stockholm, Sweden, May 1986: following the nuclear accident in Chernobyl, discussion on the future of commercial nuclear power as well as the problem of weapons of mass destruction;

- Amman, Jordan, December 1986: drafting the final report of the commission and announcement of the publication of sectoral reports on disappearances, street children, refugees and modern wars.

Commissioned preliminary research papers. 8 plenary meetings held; established working groups assisted by experts; listened to expert witnesses; periodically organized public meetings, panel discussions and seminars.

Support: Secretariat of 10 professional staff.

Funding: The Government of Switzerland provided the premises and logistical support to the Secretariat of the commission. In addition, the following Governments made financial contributions: Canada, Cyprus, Denmark, Egypt, Finland, Japan, Kuwait, Pakistan, Sweden, Tunisia and the United States, as well as the European Economic Community. The Governments of Austria, Japan, Jordan, Sweden and Tunisia also contributed towards the costs of the plenary meetings of the commission held in those countries.

The following non-governmental organizations also made financial contributions: CEBEMO (Holland), Japan Shipbuilding Foundation (Japan), Oxfam (U.K.), Radda Barnen (Sweden) and Soka Gakkai (Japan).

Approximately half of the expenses of the commission were covered through contributions from private sources. Contributions were made by the following: Prince Talal bin Abdul Aziz Al Saud, Sheikh Khalifa bin Hamad Al-Thani, Prince Karim Aga Khan, Prince Saddrudin Aga Khan, Crown Prince Hassan bin Talal, Zia Rizvi and Abbas Gokal.

\subsection{World Commission on Environment and Development}

Duration: Four years, 1984-1987.

Members: Chair: Gro Harlem Brundtland (PM of Norway),Vice-chair: Mansour Khalid (Sudan) and Susanna Agnelli (Italy), Saleh Al-Athel (Saudi Arabia), Bernard Chidzero (Zimbabwe), Lamine Fadika (Cote d'Ivoire), Volker Hauff (Federal Republic of Germany), Istvan Lang (Hungary), Ma Shijun (China), Margarita Marino de Botero (Colombia), Nagendra Singh (India), Paulo Nogueira-Neto (Brazil), Saburo Okita (Japan), Shridath Ramphal (Guyana), William Ruckelshaus (US), Mohammed Sahnoun (Algeria), Emil Salim (Indonesia), Bukar Shaib (Nigeria), Vladimir Sokolov (Soviet Union), Jjanez Stanovnik (Yugoslavia), Maurice Strong (Canada); ex officio Jim MacNeill (Canada).

\section{Work process:}

During its inaugural meeting, the Commission selected eight key issues regarding environment and development for analysis during the course of its work: 1) Perspective on population, environment, and sustainable development, 2) energy, 3) industry, 4) food security, agriculture and forestry, 5) human settlements, 6) international economic relations, 7) decision support systems for environmental management and 8) international cooperation. 
An important decision of the commission was that its work process would be open, visible and participatory and that it should receive the broadest range of views on the key issues it was addressing. During its work on the report, the commission travelled and organized public hearings in over 15 capitals on five continents, involving consultation with hundreds of government officials, scientists, industrialists, NGO representatives and the general public. These public hearings, a unique feature of the commission, became its "trademark" and have been of immeasurable benefit to the success and influence of the report.

The commission appointed a group of expert special advisors to assist it and the Secretariat in the analysis of the key issues selected. Three advisory panels of leading experts on energy, industry and food security were established to advise on the recommendations and conclusions. The commission was also assisted in its review of legal rights and principles by a group of international legal experts. The three panels and the group of experts submitted their report to the commission. Finally, more than 75 studies and reports related to the eight key issues were written by experts from all around the world as background documents, material that has provided an invaluable resource base for the final report. The body of documents studied by the commission - more than 10,000 pages - was compiled in a collection of the archives of sustainable development. Copies of this collection were then placed in six academic centres throughout the world.

Support: In July 1984, a secretariat was established in Geneva which included a Secretary-General, Jim MacNeil, 15 senior professionals and 18 general services and support staff members.

Funding: Eight sponsoring governments and substantial untied contributions from other governments, private foundations, NGOs. The commission had a budget of 6 million dollars.

\subsection{The South Commission}

Duration: 1987-1990

Members: 28 members in total; Julius Nyerere as Chairman of the commission: Ismail Sabri Abdalla (Egypt), Abdlatif Al-Hamad (Kuwait), Paula Evaristo Arns (Brazil), solita Collas-Monsod (Philippines), Eneas Da Conceiçao Comiche (Mozambique), Gamani Corea (Sri Lanka), Aboubakar Diaby-Outtara (Ivory Coast), Aldo Ferrer (Argentina), Celso Furtado (Brazil), Enrique Iglesias (Uruguay), Devaki Jain (India), Simba Makoni (Zimbabwe), Michael Manley (Jamaica), Jorge Eduardo Navarrete (Mexico), Pius Okigbo (Nigeria), Augustin Papic (Yugoslavia), Carlos Andrés Pérez (Venezuela), Qian Jiadong (China), Shridath Ramphal (Guyana), Carlos Rafael Rodriguez (Cuba), H Abdul Salam (Pakistan), Marie-Angélique Savané (Senegal), Tan Sri Ghazali Shafie (Malaysia), Tupua Tamasese Tupuola Efi (Western Samoa), Nitisastro Widjojo (Indonesia), Layachi Yaker (Algeria).

\section{Work process:}

In the months after the announcement of the South Commission and during its tenure, $\mathrm{Mr}$ Nyerere travelled widely in the South to discuss the role of the commission with people in public life, in the business and academic communities, and in non-governmental organizations. 
The commission benefited from papers contributed by experts from a number of countries as well as by several institutions. It held eight plenary meetings: Mont-Pélerin (Switzerland, 2-5October 1987); Kuala Lumpur (Malaysia, 1-3 March 1988); Cocoyoc (Mexico, 5-8 August 1988); Kuwait (10-12 December 1988); Maputo (Mozambique, 27-30 May 1989); New Delhi (India, 11-14 November 1989); Nicosia (Cyprus 4-8 May 1990); Havana (Cuba, 30-31 July 1990); Caracas (Venezuela, 23 August 1990). The final meeting was held in Arusha (Tanzania, 6-8 October 1990).

The commission also set working groups with the commissioners to deal in depth with certain issues. The secretariat of the commission convened several expert groups to assist in its work. Finally, the commission benefited from contacts with several institutions.

Funding: The South Commission's work has been supported by financial contributions from developing countries. The following countries contributed:

Algeria $(\$ 300,000)$, Argentina $(\$ 100,000)$, Bangladesh $(\$ 5,000)$, Barbados $(\$ 2,000)$, Brazil $(\$ 135,000)$, Botswana $(\$ 200,000)$, Brunei $(\$ 200,000)$, China $(\$ 400,000)$, Cuba $(\$ 200,000)$, Egypt $(\$ 100,000)$, Ghana $(\$ 100,000)$, Guyana $(\$ 10,000)$, India $(\$ 500,000)$, Indonesia $(\$ 75,000)$, Iran $(\$ 100,000)$, Jamaica $(\$ 105,000)$, Jordan $(\$ 10,000)$, Kenya $(\$ 100,000)$, P.D.R. of Korea $(\$ 20,000)$, Republic of Korea $(\$ 300,000)$, Kuwait $(\$ 500,000)$, Malaysia $(\$ 400,000)$, Maldives $(\$ 5,000)$, Mali $(\$ 32,700)$, Malta $(\$ 5,000)$, Mexico $(\$ 200,000)$, Mozambique $(\$ 50,000)$, Niger $(\$ 35,070)$, Nigeria $(\$ 400,000)$, Oman $(\$ 225,000)$, Pakistan $(\$ 20,000)$, Philippines $(\$ 20,000)$, Senegal $(\$ 49,000)$, Seychelles $(\$ 1,000)$, Singapore $(\$ 50,000)$, Sri Lanka $(\$ 10,000)$, Sudan $(\$ 100,000)$, Syria $(\$ 300,000)$, Tanzania $(\$ 50,000)$, Thailand $(\$ 50,000)$, Uganda $(\$ 100,000)$, Venezuela $(\$ 596,571)$, Yugoslavia $(\$ 159,000)$, Zambia $(\$ 67,769)$, Zimbabwe $(\$ 300,000)$.

Financial contributions were also received by: Arab Foundation for Economic and Social Development, Kuwait $(\$ 355,000)$, International Development Research Centre, Canada $(\$ 46,750)$, OPEC Fund $(\$ 100,000)$, private sector in Malaysia $(\$ 376,900)$, Third World Foundation, London $(\$ 60,000)$. Host governments met the local costs of the commission's meetings. The Federal Government of Switzerland made a contribution of Sfr. 280, 00 a year for a period of three years towards the operational expenses, including rent, of the secretariat in Geneva. The Canton of Geneva provided office furniture and equipment. The Government of Norway provided word processing equipment.

\subsection{Independent Commission on Population and Quality of Life}

Duration: 5 years, 1991-1996.

Members: 19 members and Maria de Lourdes Pintasilgo as Chairperson: Monique Bégin, Ruth Cardoso, Karina Constantino-David, Eleanor Homes Norton, Maria Anna Knothe, Bernard Kochner, Vina Mazumdar, Hanan Mikhail-Ashrawi, Taro Nakayama, Olusegun Obasanjo, Jan Pronk, Pu Shan, Augusto Ramirez Ocampo, Juan Somavia, Aminata D. Traoré, Beate Weber, Anders Wijkman, Alexander Nikolayevitch Yakovlev. 


\section{Work Process:}

Two preparatory meetings were held before the commission was finally created: London, 3 December 1991 and Bellagio Study and Conference Center, 4-5 March 1992

The commission met every six months to elaborate a shared vision and to formulate its message to be disseminated through its final report:

1) Paris, 21-23 April 1993: definition of the methodology and agenda; exchange of experiences and views regarding population matters and quality of life and their relationships with human rights, socio-economic development and environment;

2) Paris, 13-15 October 1993: confirmation of the concept of quality of life as the essential issue of the commission's work and refocusing of the concept of population on people and their life condition, with the result that the commission decided to give priority to the grass-roots work and set the guidelines for Public Hearings to be organized in several regions of the world as widely as possible;

3) New Delhi, 28-30 April 1994: agreement on the outline and general content of the report;

4) Sintra, Portugal, 4-7 February 1995: adoption of the title of the report;

5) Paris, 26 June-1 July 1995: agreement on the ultimate formulation of the conclusions and planned dissemination of the report. A Task Force of five commissioners was appointed to review the report in detail and propose a specific orientation of its final text;

6) Paris, 2-4 February 1996: adoption of the final draft of the report.

Public hearings held in 7 regions around population issues of regional interest. Consultations held with experts: Roundtable discussions with "thinkers" in conjunction with regional hearings. More than 60 research papers were commissioned.

Support: Secretariat included Executive Secretary, 13 professional staff, 5 support staff.

Funding: Funding of the commission's work came from the governments of Canada, Germany, Japan, the Netherlands, Norway, Sweden and the United Kingdom. The International Planned Parenthood Federation, the United Nation Population Fund and the World Bank also contributed. Finally, funding came from the Ford Foundation, the William and Flora Hewlett Foundation, the MacArthur Foundation, the Andrew W. Mellon Foundation and the Rockefeller Foundation.

\subsection{Commission on Global Governance}

Duration: 2.5 years, September 1992-January 1995.

Members: Co-chairs - Ingvar Carlsson and Shridath Ramphal and 26 members. 
The 28 members who served in the commission were:

Ingvarr Carlsson (Sweden) \& Shridath Ramphal (Guyana), Ali Alatas (Indonesia), Abdlatif Al-Hamad (Kuwait), Oscar Arias (Costa Rica), Anna Balletbo i Puig (Spain), Kurt Biedenkopf (Germany), Allan Boesak (South Africa), Manuel Camcho Solis (Mexico), Bernard Chidzero (Zimbabwe), Barber Conable (US), Jacques Delors (France), Jiri Dienstbier (Czech Rep), Enrique Iglesias (Uruguay), Frank Judd (UK), Hongkoo Lee (ROK), Wangari Maathai (Kenya), Sadako Ogata (Japan), Olara Otunnu (Uganda), I.G. Patel (India), Celina Vargas do Amaral Peixoto (Brazil), Jan Pronk (Netherlands), Qian Jiadong (China), Marie-Angélique Savané (Senegal), Adele Simmons (US), Maurice Strong (Canada), Brian Urquhart (UK), Yuli Vorontsov (Russia).

\section{Work process:}

Eleven commission meetings took place between September 1992 and October 1994 when the commission approved the final text of the report. The meeting were held mostly in Geneva and also once in New York, Cuernavaca (Mexico), Tokio, Brussels and Visby (Sweden).

Commission members divided themselves into four Working Groups: on 1) global values, 2) global security, 3) global development, and 4) global governance. An important basis for these discussions 21 expert papers prepared specially for the commission.

The commission launched a vast consultation round with civil society organizations. In early 1993, the co-chairs contacted more than 50 leading global NGO networks, asking them to disseminate information about the commission to their member organizations and to solicit direct feedback. The secretariat received hundreds of replies which helped the discussion within the commission.

In addition, commissioners met with NGO representatives in Geneva on two occasions during the course of preparing their report. Discussions with NGOs were also organized in association with the commission's meetings in New York, Mexico City, Delhi and Tokyo.

Among other consultations, were a number of discussions and symposia for the commission (three seminars hosted by The Common Security Forum at Harvard and Cambridge Universities; a Symposium hosted by the Norwegian Ministry for Foreign Affairs in Oslo, a Conference organized by the LSE and Political Science's Centre for the Study of Global Governance, and the UNU hosted a public symposium.

Three regional consultations were also held: a Latin American consultation in Costa Rica, in collaboration with Arias Foundation; an African consultation, in collaboration with the International Peace Academy; an Asian consultation in Delhi, in collaboration with the Rajiv Gandhi Institute for Contemporary Studies.

The final report Our Global Neighbourhood was launched at the World Economic Forum at Davos on 26 January 1995. National launches of report occurred in Brazil, Czech Republic, India, Kenya, India, Pakistan, Russia, South Africa, the United Kingdom and the United States. The full report is published in 16 languages. A popular version and a summary of conclusions and recommendations and expert papers were published separately. 
As follow-up the commission decided at an early stage to disseminate the report and actively promote its ideas and recommendations through speaking engagements, working with governments, international organizations, NGOs, the media, organizing workshops etc. The commission's secretariat has continued to function in order to coordinate this work. Finally, the commission closed its office at the end of June 2001.

Support: In May 1992, the commission established a secretariat in Geneva composed of a Secretary-General, an Executive Director (until March 1994), 3 Professional staff members and 1 General Service staff member. The commission's co-chairs also had 2 support staff members respectively. Approximately 15 additional consultants were brought in to draft the report.

Funding: The Commission received financial contributions from the governments of Canada, Denmark, India, Indonesia, the Netherlands, Norway, Sweden and Switzerland. Through the support of the government of Japan, funds were made available from two United Nations trust funds. The commission also received grants from the Arab Fund for Economic and Social Development (Kuwait) and the World Humanity Action Trust (United Kingdom), as well as from the MacArthur Foundation, the Carnegie Corporation, and the Ford Foundation (all based in the United States). The Government of Mexico City paid for travel to and local costs of a commission meeting in Mexico: the European Commission did the same for a meeting in Brussels. The Friedrich Ebert Stiftung (Germany) paid some of the travel costs for a New York meeting. The Canton of Geneva provided the commission with the free use of a house in Geneva for its secretariat.

\subsection{World Commission on Culture and Development}

Duration: 1992-1995

Members: 19 members: Five honorary members: Suu Kyi Aung San, Claude Lévi Strauss, Ilya Prigogine, Derek Walcott, Elie Wiesel: thirteen members: Lourdes Arizpe, Yoro K. Fall, Kurt Furgler, Celso Furtado, Keith Griffin, Mahbub ul Haq, Elizabeth Jelin, Angeline Kamba, Ole-Henrik Magga, Nikita Mikhalkov, Chie Nakane, Leila Takla and Javier Pérez de Cuéllar as Chairman.

\section{Work Process:}

The WCCD pursued its reflection through a combination of literature reviews on its main themes, public hearings with specialists in each of the world regions, and consultations with selected experts and institutions. It discussed the findings of research papers and essays it commissioned, and analysed the results of meetings and task forces organized in the context of its activities and the working meetings it held.

Regional consultations consisted of public hearings at which leading figures (social scientists, policy-makers, artists and cultural leaders, cultural policy and development experts, NGO activitists) shared their concerns and visions with the WCCD. Nine working meetings were organized: Paris (March 1992), Stockholm (June 1993), San José (February 1994), Yamoussoukro (June 1994), Manila (November 1994), Sultanate of Oman (January 1995), United Nations headquarters in New York (March 1995), Chiba City (June 1995), Pretoria (September 1995). These meetings resulted in a large number of briefs, papers and essays. 
In the course of its work, WCCD set in motion a dynamic of international reflection on the issues it faced. The Council of Europe, the European commission, the Organization of African Unity, and UNESCO contributed to the work of the WCCD with reports. At the same time, members of the WCCD participated in a seminar organized by the Norwegian Government ("Majority-Minority Relations: the case of the Sami in Scandinavia, Kautokeino, Norway, June 1993); a workshop on cultural diversity in South Asia organized by the International Centre for Ethnic Studies (Colombo, June 1995); and the conference "Culture and Development in the Countries in Transition" organized by the Russian Institute for Cultural Research (June 1995).

Support: The WCCD Office was established within the UNESCO Secretariat in Paris. It comprised two Executive Secretaries (Yudhishthir Raj Isar and Jérôme Bindé) and a Professional Staff and General Services.

Funding: The WCCD received funds from the governments of Canada, Denmark, Finland, Germany, the Netherlands, Norway, Sweden and Switzerland. Financial contributions came from Ecuador, Greece, Indonesia and Philippines. The United Nations Funds for Population Activities (UNFPA), the A.S. Onassis Benefit Foundation, the Organization for Co-operation and Development (OIKOS), Portugal and the InterAmerican Development Bank made contributions. The costs of organizing regional consultations and working meeting were covered by Sweden, Costa Rica, Philippines, Sultanate of Oman, Japan, the authorities of Chiba Prefecture, South Africa.

\subsection{World Commission on Dams}

Duration: $1998-2000$

Members: Commission composed of 12 members and chaired by Kader Asmal: Don Blackmore (Australia), Jose Goldemberg (Brazil), Göran Lindahl (Sweden), Medha Patkar (India), Lakshmi Chand Jain (India), Joji Cariño (Philippines), Judy Henderson (Australia), Deborah Moore (United States), Thayer Scudder (United States), Jan Veltrop (United States), Achim Steiner (Germany).

\section{Work process:}

The core of the WCD knowledge base that served to inform the commission on the main issues surrounding dams and their alternatives is made of:

- $\quad$ Eight detailed case studies of large dams (Aslantas dam, Ceyhan River Basin, Turkey; Glomma-Lågen Basin, Norway; Grand Coulee dam, Columbia River, United States/ Canada; Kariba dam, Zambezi River, Zambia/Zimbabwe; Pak Mun dam, MunMekong River Basin, Thailand; Tarbela dam, Indus River Basin, Pakistan; Tucuruí dam, Tocantins River, Brazil; Gariep and Vanderkloof dams, Orange River, South Africa pilot study);

- Country reviews for India and China plus a briefing paper on Russia and the Newly Independent States;

- A survey of 125 large dams which looked at, along with 17 thematic reviews, 1) social, environmental and economic issues, 2) alternatives to dams and 3) on governance and institutional processes.

Funding: Governments, private sector, multilateral organizations and NGOs provided funds for US\$9,700,000 (1997) 


\subsection{Commission on Macroeconomics and Health}

Duration: 2 years, January 2000-November 2001

Members: Chair Jeffrey Sachs; Isher Judge Ahluwalia, K.Y. Amoako, Eduardo Aninat, Daniel Cohen, Wephirin Diabre, Eduardo Doryan, Richard G.A. Feachem, Robert Fogel, Dean Jamison, takatoshi Kato, Nora Lustig, Anne Mills, Thorvald Moe, Manmohan Singh, Supachai Panitchpakdi, Lura Tysn, Harold Varmus.

Work Process: The six working groups reporting to the CMH were: Global Public Goods for Health, Disease Control and Prevention; Information and Dissemination of Best Practice; Mobilization of Domestic Resources for Health, Health and International Economy, Improving Health Outcomes of the Poor; Development Assistance and Health.

1st CMH Meeting, Geneva, January 2000, 2nd CMH Meeting, New Delhi, April 2000 3rd CMH Meeting, Paris, November 2000, Special Africa Meeting, Bellagio, Italy, February 2001, 4th CMH Meeting, Addis Ababa, March 2001

Support came from all of the Working Group Chairs, and the commissioners acknowledged the work of Chairs Isher Judge Alhuwalia, George Alleyne, Kwesi Botchwey, Daniel Cohen, Zephirin Diabre, Richard Feachem, Prabhat Jha, Chris Lovelace, Anne Mills, Carin Norberg, and Alan Tait.

Support: WHO Director-General Dr. Gro Harlem Brundtland actively supported the work of the commission. The WHO Secretariat, led by Sergio Spinaci, with able assistance provided by 3 staff members supported the Project in every way and has assisted the commissioners.

Funding: The commission gratefully acknowledges the financial support provided by the Bill and Melinda Gates Foundation, the United Kingdom Department for International Development, the Grand Duchy of Luxembourg, the Government of Ireland, the Government of Norway, the Rockefeller Foundation, the Government of Sweden, and the United Nations Foundation.

\subsection{International Commission on Intervention and State Sovereignty}

Duration: One year mandate, Sept 2000-Sept 2001.

Members: Co-chairs: Gareth Evans and Mohammed Sahnoun: 10 members appointed by the Canadian Government $=12$ in total: Gisèle Côté-Harper (Canada), Lee Hamilton (United States), Michael Ignatieff (Canada), Vladimir Likin (Russia), Klaus Naumann (Germany), Cyril Ramaphosa (South Africa), Fidel V. Ramos (Philippines), Cornelio Sommaruga (Switzerland), Eduardo Stein Barillas (Guatemala), Ramesh Thakur (India).

\section{Work Process:}

An Advisory Board was appointed as political reference point for ICISS. Its aim was

1) supporting commissioners by grounding their report in current political realities and

2) assisting in building the political momentum and public engagement required to follow up the ICSS recommendations. A Commission's Research Directorate, led jointly by 
Professor Thomas G. Weiss of City University of New York (CUNY) and Stanlake J.T.M. Samkange of Zimbabwe, supplemented and consolidated the intellectual dimension of ICISS's work. And a small secretariat, provided as part of the Canadian Government support for ICISS and housed within the Department of Foreign Affairs and International Trade in Ottawa, administered the ICISS work plan.

Five full meetings were organized in order to identify central questions, key issues and general approach. They were held in Ottawa (November 5-6, 2000), Maputo (March 1112, 2001), New Delhi (June 11-12, 2001), Wakefield (August 5-9, 2000), Brussels (September 30, 2001).

Eleven regional roundtables and national consultations were also held in order to stimulate debate and ensure that the ICISS had the broadest possible range of views during the course of its mandate. National and regional officials, senior representatives of major international organizations and $\mathrm{UN}$ agencies, representatives of civil society, nongovernmental organizations (NGOs), academic institutions and think-tanks attended the meetings.

Commissioners drew upon the record of debate and discussion generated at the UN and in regional and other forums, the already published scholarly and policy research and a series of papers and studies specially commissioned for the ICISS. This programme of research was consolidated by the Research Directorate, which produced research papers and assisted the ICISS in the drafting of its report.

Support: Secretariat based in Canadian Ministry of Foreign Affairs and Trade, Ottawa. A 15-member Advisory Board established to give political support and direction.

Funding: The Government of Canada provided US\$ 1 million to support the work of the commission, and financial contributions have also been received from the Governments of United Kingdom and Switzerland.

Several institutional foundations have given strong political and financial support (including the Carnegie Corporation of New York, The William and Flora Hewlett Foundation, the John D. and Catherine T. MacArthur Foundation, the Rockefeller Foundation and the Simons Foundation).

\subsection{Commission on Human Security}

Duration: 2 year mandate, January 2001-December 2002.

Members: Co-chairs: Sadako Ogata and Amartya Sen: 10 members appointed by Japanese government, 12 in total. The ten commissioners were: Prof. Bronislaw Geremek, Ambassador Lakhdar Brahimi, Dr. Lincoln C. Chen, Dr. Frene Frenny Noshir Ginwala, Ms. Sonia Picado, Dr. Surin Pitsuwan, Dr. Donna E. Shalala, Mr. Peter Sutherland, Professeur Albert Tevoedjre, and Mr. Carl Tham.

\section{Work process:}

Four meetings were organized: Whitney Greentree Estate, New York (8-10 June 2001), Tokyo (16-17 December 2001), Stockholm (9-10 June 2002) and Thailand (26-27 January 2003). 
One-day symposiums on human security have also been organized with the participation of external experts: "Symposium on Human Rights and Human Security", San José, Costa Rica (1 December 2001); "Workshop on Measurements of Human Security" (Harvard University JFK School of Government, 30 November 2001); "Workshop on Education, Equity and Security" (Kolkata, 2-4 January 2002); "Human Security, Human Rights and Human Development" (Harvard Kennedy School, 2 February 2002);

Support: The secretariat supported the work of the commission by undertaking and coordinating research and outreach activities, preparing substantive discussion papers, including the commission's final report and assisting commissioners in their activities to promote human security.

Funding: Chiefly funded by the UN Trust Fund for Human Security, which was established by deceased former Prime Minster of Japan, Keizo Obuchi, in March 1999, with initial funding of approximately 10 billion yen (US\$ 86.2 million). Former Prime Minister Yoshiro Mori announced his intention to increase the amount by another 10 billion yen, in his address at the UN Millennium Summit in September 2000. The Government of Japan made an additional contribution through UNHCR to enable the secretariat to service the Commission. The Rockefeller and the Whitney Greentree Foundations made the meeting possible with financial and logistical support. 


\section{Policy Integration Department Working Papers prepared for the World Commission on the Social Dimension of Globalization}

No. 16 International finance: Meeting the needs of people in developing countries, José Guilherme Almeida dos Reis

No. 17 The gender dimensions of globalisation of production, Stephanie Barrientos, Naila Kabeer and Naomi Hossain

No. 18 Social exclusion in the context of globalization, Jan Breman

No. 19 Gender and globalization: A macroeconomic perspective, Çağatay Nilüfer and Ertük Korkurt

No. 20 Globalization, social exclusion, and work: With special reference to informal employment and gender, Marilyn Carr and Martha Chen

No. 21 Resources for social development, Antony Clunies Ross

No. 22 Does the new international trade regime leave room for industrialization policies in the middle-income countries?, Alisa DiCaprio and Alice Amsden

No. 23 Social dimension of globalisation in Latin America: Lessons from Bolivia and Chile, Alvaro García Hurtado

No. 24 Globalization: Social impact and policy actions: A partly annotated bibliography, Bernhard Gunter and Rolph van der Hoeven

No. 25 The social dimension of global production systems, Susan Hayter

No. 26 Reforming global economic and social governance:

a critical review of recent programmatic thinking, Jeremy Heimans

No. 27 Corporate social responsibility: An issues paper, Michael Hopkins

No. 28 Upgrading in global value chains, John Humphrey

No. 29 Implications of globalization and economic restructuring for skills development in Sub-Sahara Africa, Richard K. Johanson

No. 30 The outcome and impact of the main international commissions on development issues, Frédéric Lapeyre

No. 31 Globalization and structural adjustment as a development tool, Frédéric Lapeyre

No. 32 Globalization and perceptions of social inequality, Malte Luebker

No. 33 The changing structure of trade linked to global production systems: what are the policy implications?, William Milberg

No. 34 Corporate social responsibility: An overview of principles and practice, Jill Murray

No. 35 Inclusive development strategy in an era of globalization, Ignacy Sachs

No. 36 Social consequences of the globalization of the media and communications sector: Some strategic considerations, Seán Ó. Siochrú

No. 37 Globalization, history and international migration - A view from Latin America, Andrés Solimano

No. 38 Towards a different kind of globalization, or how the anti-globalizers view the world, Gijsbert van Liemt 
